\title{
OH reactivity in a South East Asian tropical rainforest during the Oxidant and Particle Photochemical Processes (OP3) project
}

\author{
P. M. Edwards ${ }^{1, *}$, M. J. Evans ${ }^{2, * *, * * *}$, K. L. Furneaux ${ }^{1, \dagger}$, J. Hopkins ${ }^{4,5}$, T. Ingham ${ }^{1,3}$, C. Jones ${ }^{4, * * * *}$, J. D. Lee ${ }^{4,5}$, \\ A. C. Lewis ${ }^{4,5}$, S. J. Moller ${ }^{4,5}$, D. Stone ${ }^{1}$, L. K. Whalley ${ }^{1,3}$, and D. E. Heard ${ }^{1,3}$ \\ ${ }^{1}$ School of Chemistry, University of Leeds, Woodhouse Lane, Leeds, LS2 9JT, UK \\ ${ }^{2}$ School of Earth and Environment, University of Leeds, Woodhouse Lane, Leeds, LS2 9JT, UK \\ ${ }^{3}$ National Centre for Atmospheric Science, University of Leeds, Leeds, LS2 9JT, UK \\ ${ }^{4}$ Department of Chemistry, University of York, Heslington, YO10 5DD, UK \\ ${ }^{5}$ National Centre for Atmospheric Science, University of York, Heslington, YO10 5DD, UK \\ *now at: Earth System Research Laboratory, Chemical Sciences Division, NOAA, 325 Broadway, Boulder, \\ Colorado 80305, USA \\ *** now at: Department of Chemistry, University of York, Heslington, YO10 5DD, UK \\ *** now at: National Centre for Atmospheric Science, University of York, Heslington, YO10 5DD, UK \\ **** Graduate School of Global Environmental Studies, Kyoto University, Yoshida-Honmachi, Sakyo-ku, \\ Kyoto 606-8501, Japan \\ ${ }^{\dagger}$ sadly passed away on 28 July 2009
}

Correspondence to: D. E. Heard (d.e.heard@leeds.ac.uk)

Received: 24 January 2013 - Published in Atmos. Chem. Phys. Discuss.: 22 February 2013

Revised: 13 August 2013 - Accepted: 14 August 2013 - Published: 26 September 2013

\begin{abstract}
OH}$ (hydroxyl radical) reactivity, the inverse of the chemical lifetime of the hydroxyl radical, was measured for 12 days in April 2008 within a tropical rainforest on Borneo as part of the OP3 (Oxidant and Particle Photochemical Processes) project. The maximum observed value was $83.8 \pm 26.0 \mathrm{~s}^{-1}$ with the campaign averaged noontime maximum being $29.1 \pm 8.5 \mathrm{~s}^{-1}$. The maximum $\mathrm{OH}$ reactivity calculated using the diurnally averaged concentrations of observed sinks was $\sim 18 \mathrm{~s}^{-1}$, significantly less than the observations, consistent with other studies in similar environments. $\mathrm{OH}$ reactivity was dominated by reaction with isoprene $(\sim 30 \%)$. Numerical simulations of isoprene oxidation using the Master Chemical Mechanism (v3.2) in a highly simplified physical and chemical environment show that the steady state $\mathrm{OH}$ reactivity is a linear function of the $\mathrm{OH}$ reactivity due to isoprene alone, with a maximum multiplier, to account for the $\mathrm{OH}$ reactivity of the isoprene oxidation products, being equal to the number of isoprene $\mathrm{OH}$ attackable bonds (10). Thus the emission of isoprene constitutes a significantly larger emission of reactivity than is offered by the primary reaction with isoprene alone, with significant scope
\end{abstract}

for the secondary oxidation products of isoprene to constitute the observed missing $\mathrm{OH}$ reactivity. A physically and chemically more sophisticated simulation (including physical loss, photolysis, and other oxidants) showed that the calculated $\mathrm{OH}$ reactivity is reduced by the removal of the $\mathrm{OH}$ attackable bonds by other oxidants and photolysis, and by physical loss (mixing and deposition). The calculated $\mathrm{OH}$ reactivity is increased by peroxide cycling, and by the $\mathrm{OH}$ concentration itself. Notable in these calculations is that the accumulated $\mathrm{OH}$ reactivity from isoprene, defined as the total $\mathrm{OH}$ reactivity of an emitted isoprene molecule and all of its oxidation products, is significantly larger than the reactivity due to isoprene itself and critically depends on the chemical and physical lifetimes of intermediate species. When constrained to the observed diurnally averaged concentrations of primary VOCs (volatile organic compounds), $\mathrm{O}_{3}, \mathrm{NO}_{\mathrm{x}}$ and other parameters, the model underestimated the observed diurnal mean $\mathrm{OH}$ reactivity by $30 \%$. However, it was found that (1) the short lifetimes of isoprene and $\mathrm{OH}$, compared to those of the isoprene oxidation products, lead to a large variability in their concentrations and so significant variation 
in the calculated $\mathrm{OH}$ reactivity; (2) uncertainties in the $\mathrm{OH}$ chemistry in these high isoprene environments can lead to an underestimate of the $\mathrm{OH}$ reactivity; (3) the physical loss of species that react with $\mathrm{OH}$ plays a significant role in the calculated $\mathrm{OH}$ reactivity; and (4) a missing primary source of reactive carbon would have to be emitted at a rate equivalent to $50 \%$ that of isoprene to account for the missing $\mathrm{OH}$ sink. Although the presence of unmeasured primary emitted VOCs contributing to the measured $\mathrm{OH}$ reactivity is likely, evidence that these primary species account for a significant fraction of the unmeasured reactivity is not found. Thus the development of techniques for the measurement of secondary multifunctional carbon compounds is needed to close the $\mathrm{OH}$ reactivity budget.

\section{Introduction}

The hydroxyl radical $(\mathrm{OH})$ is the dominant oxidant in the troposphere. It is highly reactive leading to low concentrations (globally averaged $\sim 1 \times 10^{6}$ molecule $\mathrm{cm}^{-3}$; Lelieveld et al., 2004) and short lifetimes ( $1 \mathrm{~s}$; Heard and Pilling, 2003; Stone et al., 2012). Reaction with $\mathrm{OH}$ is the dominant removal mechanism for methane and it plays a central role in the production of ozone $\left(\mathrm{O}_{3}\right)$ and secondary organic aerosol (SOA). $\mathrm{OH}$ thus plays an important role in understanding climate and air quality. Observations of $\mathrm{OH}$ concentrations have been available for almost three decades and the ability of models to simulate these concentrations has been considered a metric of our understanding of tropospheric chemistry (Logan et al., 1981; Heard and Pilling, 2003). However, given the close chemical coupling between its production and loss terms, there is a potential that a model may successfully reproduce the observed $\mathrm{OH}$ concentrations but for the wrong reasons. The ability to explicitly measure the rates of production or loss of $\mathrm{OH}$ offer a strong constraint on our understanding of tropospheric chemistry.

Measurements of the chemical loss rate of $\mathrm{OH}(\mathrm{OH}$ reactivity) in the atmosphere have been performed since 2001 (Kovacs and Brune, 2001). Although high $\mathrm{OH}$ reactivities have been observed in both urban and forested environments (Shirley et al., 2006; Sinha et al., 2008, 2010, 2012; Dolgorouky et al., 2012; Di Carlo et al., 2004), the ability of models to simulate these $\mathrm{OH}$ reactivity observations varies greatly. As a general trend, it has been found that our understanding is best in clean marine or high $\mathrm{NO}_{\mathrm{x}}$ environments, where the reaction of $\mathrm{OH}$ and $\mathrm{NO}_{2}$ is the main constituent of the total OH loss (Ren et al., 2003; Di Carlo et al., 2004; Lee et al., 2009; Lou et al., 2010; Dolgorouky et al., 2012). The greatest discrepancies between measured and calculated $\mathrm{OH}$ reactivity are usually found under low $\mathrm{NO}_{\mathrm{x}}$ conditions in the presence of elevated levels of volatile organic compounds (VOCs), typical of those found in forested locations (Di Carlo et al., 2004; Sinha et al., 2008, 2010; Nölscher et al., 2012), or in highly processed continental air masses (Dolgorouky et al., 2012; Sinha et al., 2012).

This failure to account for $\mathrm{OH}$ sinks within remote forested regions is significant, as they constitute the overwhelming source of reactive carbon entering into the troposphere. Biogenic volatile organic compounds (BVOCs) are emitted in large quantities $\left(\sim 1000 \mathrm{TgC} \mathrm{yr}^{-1}\right.$; Goldstein and Galbally, 2007) and play a significant role in the chemistry of the troposphere. This flux of carbon is dominated by the emission of isoprene $\left(\mathrm{C}_{5} \mathrm{H}_{8}\right)$, with monoterpenes $\left(\mathrm{C}_{10} \mathrm{H}_{16}\right)$ also playing an important role (Guenther et al., 1995, 2006). The tropics are the principal region for this emission, given their large size and high biogenic productivity. Despite their importance, the oxidation chemistry of these BVOCs is complex and, especially in the case of isoprene, is currently subject to some debate (Lelieveld et al., 2008; Paulot et al., 2009a, b; Peeters et al., 2009). Biogenic hydrocarbons as well as being $\mathrm{OH}$ sinks themselves generate oxidation products that also constitute sinks for $\mathrm{OH}$.

There have been a small number of $\mathrm{OH}$ reactivity studies in remote forested environments, predominantly in extratropical regions. For example, measurements of $\mathrm{OH}$ reactivity alongside a suite of BVOCs in a deciduous forest, at the PROPHET field site, inferred a missing OH sink corresponding to up to $50 \%$ of the measured $\mathrm{OH}$ reactivity, correlating with temperature, and potentially indicating that the unmeasured species may have emissions driven by temperature such as monoterpenes (Di Carlo et al., 2004). Sinha et al. (2010) made brief observations of $\mathrm{OH}$ reactivity alongside measurements of $\sim 30$ other compounds in a boreal forest in Finland, in 2008, and found missing OH sinks of between 25 and $75 \%$ of the total measured $\mathrm{OH}$ reactivity. These missing $\mathrm{OH}$ sinks were again attributed largely to unmeasured BVOCs. A one-dimensional model study of the same 2008 data set from Finland (Mogensen et al., 2011) also attributed the missing observed $\mathrm{OH}$ reactivity to an unmeasured primary emitted BVOC, as well as uncertainties in the rate constants used in the chemical mechanism. A more recent study by Nölscher et al. (2012), at the same site in Finland, made observations of $\mathrm{OH}$ reactivity both within and above the canopy and found a $58 \%$ missing $\mathrm{OH}$ reactivity for "normal" boreal conditions. The presence of significant concentrations of unmeasured BVOCs in forested environments was also a conclusion of Holzinger et al. (2005), who reported emissions of highly reactive BVOCs in a ponderosa pine forest in California, inferred from the presence of large quantities of previously unreported oxidation products, measured by proton transfer mass spectrometry (PTR-MS).

Despite their importance, observations of $\mathrm{OH}$ reactivity from the tropical rainforest are sparse. The only previously reported observations of $\mathrm{OH}$ reactivity were those by Sinha et al. (2008), who report values for approximately $2 \mathrm{~h}$ from within the Amazon forest canopy, Suriname, in October 2005. Average observed $\mathrm{OH}$ reactivity was approximately $53 \mathrm{~s}^{-1}$, peaking to $72 \pm 18 \mathrm{~s}^{-1}$. The calculated $\mathrm{OH}$ 
reactivity from measured $\mathrm{OH}$ sinks was found to account for only $\sim 35 \%$, indicating the presence of a large missing $\mathrm{OH}$ sink in this tropical forest environment. Unfortunately, the limited data coverage of $\mathrm{OH}$ reactivity observations during this study meant that any conclusions about the potential identity of this missing $\mathrm{OH}$ sink were difficult to make.

This failure to reconcile measurements of $\mathrm{OH}$ sinks with observed $\mathrm{OH}$ reactivity in biogenically active environments is generally attributed to unmeasured primary emitted BVOCs, implying a globally significant missing carbon source entering into the atmosphere with concomitant implications for climate and air quality. However, other studies suggest that the missing reactivity is due to unmeasured oxidation products of measured primary emitted VOCs (Kovacs et al., 2003; Hofzumahaus et al., 2009; Lou et al., 2010). This role of oxidation products is supported by recent observations by Kim et al. (2011) of OH reactivity within branch enclosures on four different tree species, where no significant oxidation chemistry had taken place, which found that the observed $\mathrm{OH}$ loss rate could be accounted for by the measured BVOCs. Although this result cannot be generalised to the plethora of plant species present in a rainforest, this work suggests that the missing $\mathrm{OH}$ sink found in the forest boundary layer may be due to unmeasured oxidation products of the initially emitted primary BVOC rather than unmeasured primary species.

The OP3 (Oxidant and Particle Photochemical Processes) (Hewitt et al., 2010) project was a field campaign that took place in a remote tropical forest location in Malaysian Borneo during which observations of $\mathrm{OH}$ reactivity were made for a continuous period of approximately 2 weeks. After introducing the observations this paper considers a theoretical framework for the reactivity of a low $\mathrm{NO}_{\mathrm{x}}$ high-VOC chemical system in relation to the flux of carbon into the system (Sect. 4). Once this conceptual system has been developed, the $\mathrm{OP} 3 \mathrm{OH}$ reactivity observations are placed into this context and the sources of $\mathrm{OH}$ reactivity in the forest are outlined and investigated.

\section{The OP3 campaign}

The OP3 campaign aimed to address uncertainties in biogenic VOC processing in and around remote, low $\mathrm{NO}_{\mathrm{x}}$, tropical forested environments on local, regional and global scales (Hewitt et al., 2010). The ground based measurements were located at the Bukit Atur Global Atmospheric Watch (GAW) station $\left(4^{\circ} 58^{\prime} \mathrm{N}, 117^{\circ} 49^{\prime} \mathrm{E}\right.$, elevation $\left.426 \mathrm{~m}\right)$ in the Danum Valley Conservation Area. Observations were made during April-May 2008, from a clearing atop a hill surrounded by pristine rainforest, in the Sabah region of northern Borneo. The complex terrain surrounding the site means that local dynamics have significant implications for interpreting chemical processes at the site. In particular it has been suggested that, although during the day the site was in a well- mixed planetary boundary layer (Hewitt et al., 2010), at night the hilltop location was above the nighttime boundary layer (Pike et al., 2010; Pugh et al., 2010).

A range of observations were made during the campaign, but critical for this study were observations of $j\left(\mathrm{O}^{1} \mathrm{D}\right)(2 \pi$ Filter radiometer; Bohn et al., 2008), $\mathrm{O}_{3}$ (Thermo Environmental Instruments 49C UV absorption instrument), hydrocarbons (GC-FID; Jones et al., 2011), and $\mathrm{NO}_{\mathrm{x}}$ (Ecophysics CLD 780TR/PLC 760SR chemiluminescence instrument). Instrument inlets were all co-located with that of the $\mathrm{OH}$ instrument to ensure sampling from the same air mass (Hewitt et al., 2010). The diurnally averaged concentrations of the observed species are shown in Fig. 1. Isoprene oxidation products, such as methyl vinyl ketone (MVK) and methacrolein (MACR), were measured at a height of $75 \mathrm{~m}$ in the forest canopy by PTR-MS (Langford et al., 2010). However, due to significant differences in the isoprene concentration measured at $5 \mathrm{~m}$ and at $75 \mathrm{~m}$ (Jones et al., 2011) it was decided that observations made at $75 \mathrm{~m}$ could not be used to constrain the observed $\mathrm{OH}$ sinks at $5 \mathrm{~m}$, and the concentrations of these oxidation products should instead be calculated by the chemistry scheme.

$\mathrm{OH}$ reactivity and $\mathrm{OH}$ concentration measurements were made by the University of Leeds' FAGE (Fluorescence Assay by Gas Expansion) instrument (Whalley et al., 2010; Ingham et al., 2009). The Leeds $\mathrm{OH}$ reactivity instrument (full description given in Ingham et al., 2009) is composed of a moveable injector inside a polytetrafluoroethylene (PTFE) flow tube. $\mathrm{OH}$ is made inside the movable injector via the photolysis of water vapour at $185 \mathrm{~nm}$ using a mercury lamp. This flow of artificially generated $\mathrm{OH}$ is injected into a turbulent flow (Reynolds number > 3950) of ambient air, which is drawn down the PTFE flow tube. The $\mathrm{OH}$ concentration generated within the flow tube is kept sufficiently low $([\mathrm{OH}]$ $\approx 10^{8}$ molecule $\mathrm{cm}^{-3}$ ) that pseudo-first-order conditions are maintained, meaning the absolute $\mathrm{OH}$ concentration does not need to be known. The FAGE technique (Heard and Pilling, 2003 ) is used to detect the $\mathrm{OH}$ via laser-induced fluorescence at low pressure. The $\mathrm{OH}$ residence time within the ambient airflow can be calculated from the measured flow velocity and known injector position relative to the sampling point for $\mathrm{OH}$ detection. Moving the injector in relation to the sampling pinhole of the detection cell is performed to vary the residence time. As the residence time is increased, the signal $(S)$ due to $\mathrm{OH}$ decreases as the radicals react with species present in the ambient air sample and are lost to the flow tube walls. The loss of $\mathrm{OH}$ within the flow tube can thus be considered in terms of a chemical loss $\left(k_{\mathrm{OH}}^{\prime}\right)$ due to the composition of the gas phase components flowing through the system and a physical loss of $\mathrm{OH}$ to the flow tube walls $\left(k_{\text {phys }}^{\prime}\right)$. The $\mathrm{OH}$ exponential decay is described by equation Eq. (1):

$[\mathrm{OH}]_{t}=[\mathrm{OH}]_{0} \exp \left(-k_{\mathrm{OH}} t\right)$, 

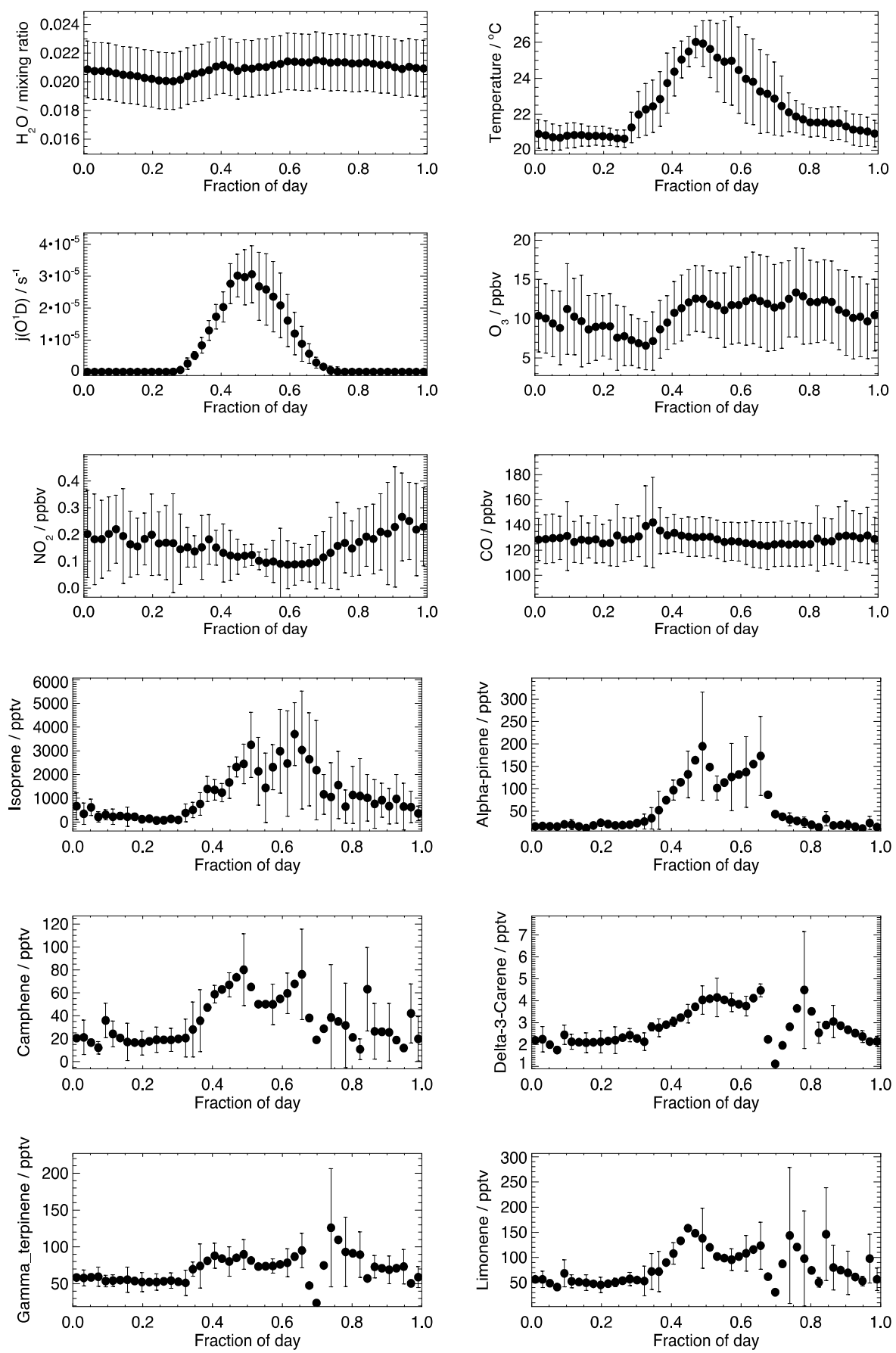

Fig. 1. Average diurnal cycles (local time) of measured species used to constrain the model, averaged into 30 min time bins, with error bars indicating the $1 \sigma$ variability on the observations. All average values are means, except for $\mathrm{NO}_{2}$ where the median has been used due to large spikes in the data. For hydrocarbons where the sampling period was less than every 30 min, the data were interpolated between their measurement points.

where $k_{\mathrm{OH}}=k_{\mathrm{OH}}^{\prime}+k_{\text {phys }}^{\prime}$. Thus,

$\ln \frac{[\mathrm{OH}]_{t}}{[\mathrm{OH}]_{0}}=\ln \left(\frac{S_{t}}{S_{0}}\right)=-\left(k_{\mathrm{OH}}^{\prime}+k_{\text {phys }}^{\prime}\right) t$, where $[\mathrm{OH}]_{0}$ and $[\mathrm{OH}]_{t}$ are the initial $\mathrm{OH}$ concentration and that at time $t$ respectively, and $S_{0}$ and $S_{t}$ are the observed LIF (laser-induced fluorescence) signals at these two times, respectively. 

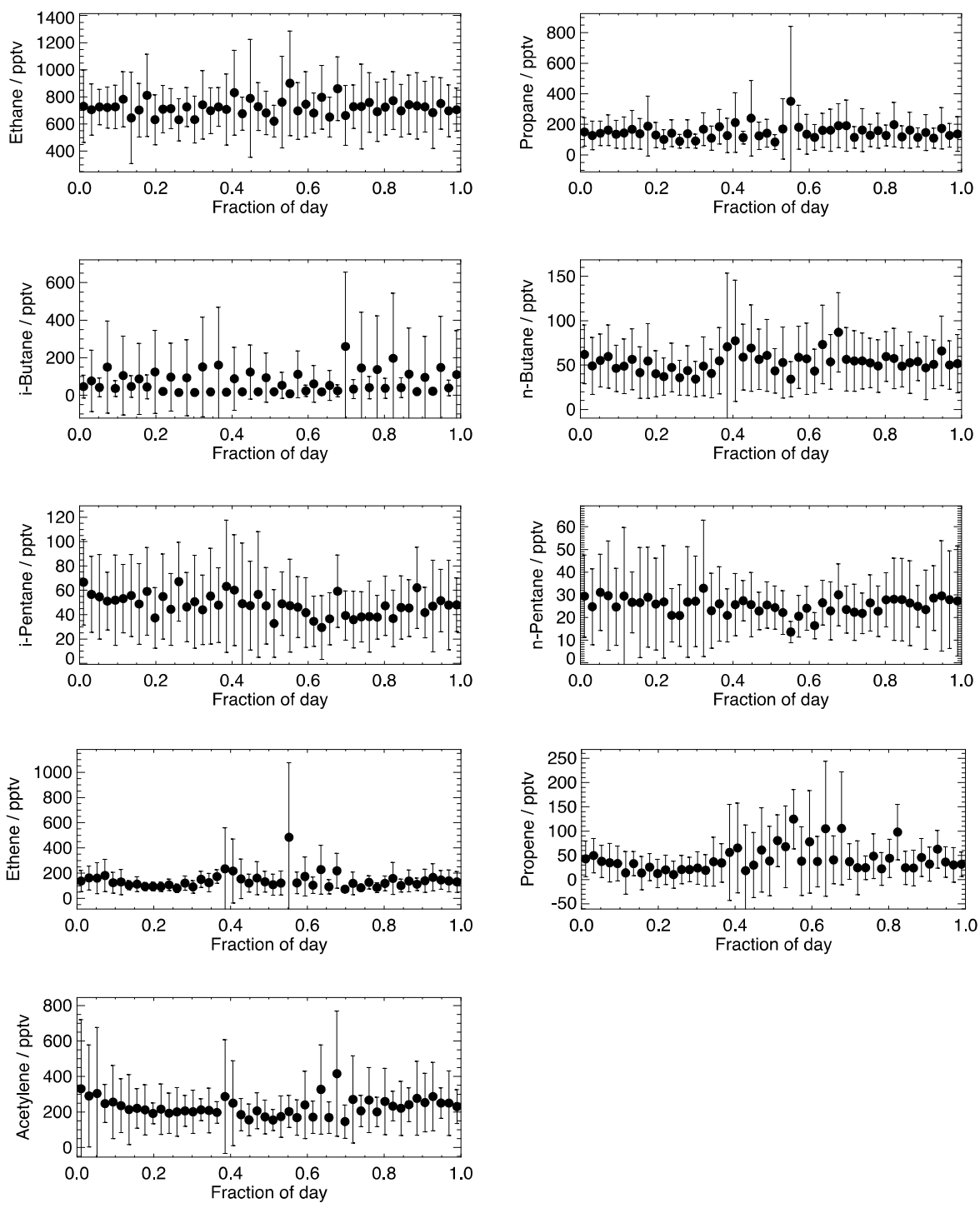

Fig. 1. Continued.

Previous calibrations of the detection of $\mathrm{OH}$ within the $\mathrm{OH}$ reactivity instrument have demonstrated a linear relationship between $\mathrm{OH}$ concentration and signal (Whalley et al., 2010). Thus a plot of $\ln (\mathrm{OH}$ signal) (with any background subtracted) versus residence time, $t$, yields a straight line with slope equal to $-\left(k_{\mathrm{OH}}^{\prime}+k_{\text {phys }}^{\prime}\right) \cdot k_{\text {phys }}^{\prime}$ is then determined experimentally by flowing zero air (Air products $99.999 \%$ ) down the flow tube and measuring the rate of $\mathrm{OH}$ decay (for this study the observed $k_{\text {phys }}^{\prime}=6.1 \pm 0.7 \mathrm{~s}^{-1}$ ).

Figure 2 shows a typical $\mathrm{OH}$ decay measured in the field during the OP3 campaign. Decays were measured over a period of approximately $100 \mathrm{~s}$, with $10 \mathrm{~s}$ spent at each injector position. A linear least-squares fit, taking into account errors in the $X$ and $Y$ coordinates, namely the $1 \sigma$ variability on the $\log$ of the $\mathrm{OH}$ signal during each $10 \mathrm{~s}$ measurement at a particular injector position and the uncertainty on the reaction time, was performed to extract the observed $k_{\mathrm{OH}}^{\prime}$. The uncertainty on the calculated reactivity is the combination in quadrature of the error on the gradient obtained from the linear fit and the $1 \sigma$ uncertainty on the measured value of $k_{\text {phys }}^{\prime}$ (Ingham et al., 2009).

A reduction in the $\mathrm{OH}$ reactivity from the true value due to the conversion of $\mathrm{HO}_{2}$ (which is generated together with $\mathrm{OH}$ inside the injector) to $\mathrm{OH}$ by its reaction with $\mathrm{NO}$ has been identified (Kovacs et al., 2003; Ingham et al., 2009). However, during the OP3 campaign, the average NO concentration during the period of $\mathrm{OH}$ reactivity observations was $42 \mathrm{pptv}$. At these concentrations the rate of $\mathrm{OH}$ production from $\mathrm{HO}_{2}+\mathrm{NO}$ is insignificant and does not perturb the $\mathrm{OH}$ decay (Ingham et al., 2009). 


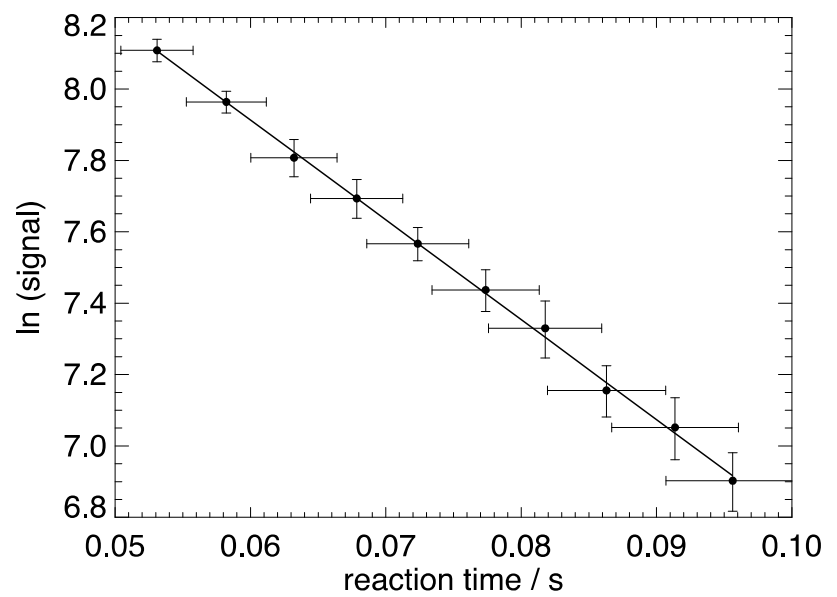

Fig. 2. Decay of $\mathrm{OH}$ measured between 12:25-12:27 Malaysia time zone $(\mathrm{UTC}+8 \mathrm{~h})$ on 21 April 2008 during the OP3 campaign, showing the line of best fit used to calculate the $\mathrm{OH}$ reactivity. The linear least squares fit to this decay yields an $\mathrm{OH}$ reactivity of $22.8 \pm 2.9 \mathrm{~s}^{-1}$, after the subtraction of $k_{\mathrm{phys}}^{\prime}$. Error bars represent the $1 \sigma$ variability on the $\mathrm{OH}$ signal during each $10 \mathrm{~s}$ measurement and the total calculated $1 \sigma$ uncertainty on the residence time.

\section{Observations of $\mathrm{OH}$ reactivity}

$\mathrm{OH}$ reactivity observations were made on 12 days between 14 and 28 April 2008 (Fig. 3), from a height of approximately $5 \mathrm{~m}$ in a forest clearing. Figure 3 shows the $1071 \mathrm{OH}$ reactivity observations made, with the error bars indicating the uncertainty on each individual observation (see Sect. 2). The maximum observed $\mathrm{OH}$ reactivity was $83.6 \pm 26.0 \mathrm{~s}^{-1}$ (the variation here represents the uncertainty on this one observation rather than a typical uncertainty). The average diurnal variation is shown in Fig. 4 with $\mathrm{OH}$ reactivity peaking at an average of $29.1 \pm 8.5 \mathrm{~s}^{-1}$ (the variation here represents the standard deviation in the observations in each $30 \mathrm{~min}$ time bin) in the early afternoon, and dropping to a minimum of approximately $7 \pm 3 \mathrm{~s}^{-1}$ just before dawn. The nighttime $\mathrm{OH}$ reactivity observations show significantly less variability than the those during the day, with a mean and standard deviation of 9.6 and $3.0 \mathrm{~s}^{-1}$ respectively compared to 20.3 and $10.1 \mathrm{~s}^{-1}$ for the daytime, suggesting different chemical regimes operating between the day and night. This difference is in part due to local meteorological conditions, as Pike et al. (2010) show that the Bukit Atur site was above the surrounding boundary layer on many nights during OP3, as a consequence of the complex local topography, resulting in increased dilution and thus a reduction in both the magnitude and the variability of the total $\mathrm{OH}$ sink. In contrast, during the day, the low winds experienced throughout the campaign (Hewitt et al., 2010) allowed BVOCs emitted from the forest to be confined to the local boundary layer. This daytime meteorology likely also increases the variability seen in the $\mathrm{OH}$ reactivity observations, as the measurement site is no longer separated from

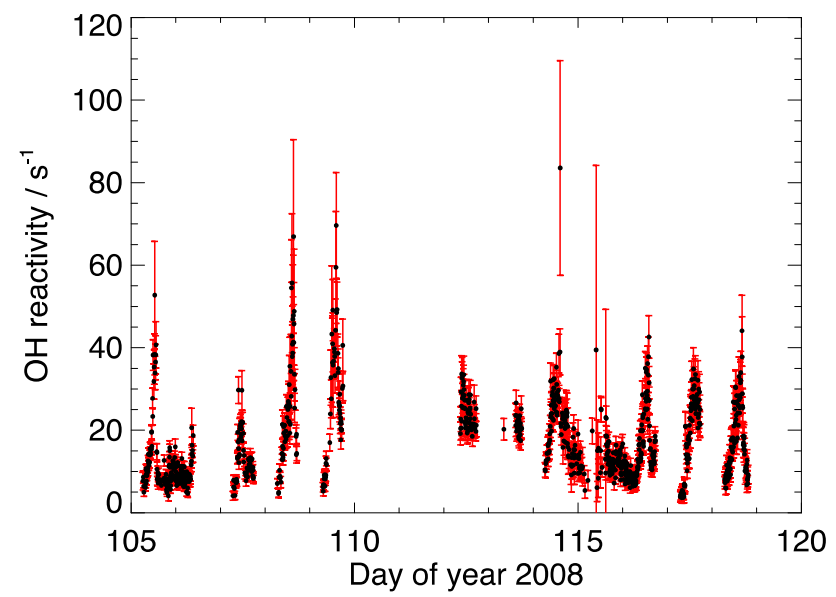

Fig. 3. OH reactivity observation time series for the OP3 campaign, with error bars indicating the $1 \sigma$ uncertainty of the measurements described in Sect. 3.

the majority of the surrounding forest and can thus be influenced by more variable air masses. This complex meteorology, combined with the temperature and light dependencies of many BVOC emission rates (Guenther et al., 1995), results in higher and more variable $\mathrm{OH}$ reactivity during the day.

Figure 4 also shows the calculated $\mathrm{OH}$ reactivity from the observations of $\mathrm{OH}$ sinks shown in Fig. $1\left(\mathrm{NO}_{2}, \mathrm{CO}\right.$, isoprene, $\alpha$-pinene, $\beta$-pinene, camphene, $\Delta$-3-Carene, $\gamma$ terpinene, limonene, ethane, propane, $i$-butane, $n$-butane, $i$ pentane, $n$-pentane, ethene, propene, acetylene, methane) (blue), and the calculated $\mathrm{OH}$ reactivity from reaction with just isoprene (green). This $\mathrm{OH}$ reactivity calculated using the supporting measurements underestimates the average observations by as much as $70 \%$, in keeping with previous studies of $\mathrm{OH}$ reactivity in forested regions (Di Carlo et al., 2004 (PROPHET); Sinha et al., 2008 (GABRIEL), 2010 $(\mathrm{BFORM}))$. The $\mathrm{OH}$ reactivity calculated from just the measured isoprene shows an almost identical trend to the full calculation, as isoprene accounts for up to $80 \%$ of the calculated reactivity.

Figure 5 is the observed $\mathrm{OH}$ reactivity data plotted against the $\mathrm{OH}$ reactivity calculated for isoprene alone (i.e. the $\mathrm{OH}+$ isoprene rate constant multiplied by the observed isoprene concentration at each point). Although the data shown in Fig. 5 exhibit a large degree of variability, likely due to observed variations in the mix of primary BVOC and secondary compounds contributing to $\mathrm{OH}$ reactions as well as the influence of different meteorological conditions, it does have some correlation $\left(r^{2}=0.5\right)$. The best fit gradient of this plot $(2 \pm 0.2)$ gives the average number of $\mathrm{OH}$ radicals lost per isoprene molecule, and despite the observed variability in the data is significantly higher than the gradient calculated from the observed compounds which react with $\mathrm{OH}(1.1 \pm 0.01)$. The small increase in the gradient calculated from the observations above unity reflects the correlation in the diurnal 


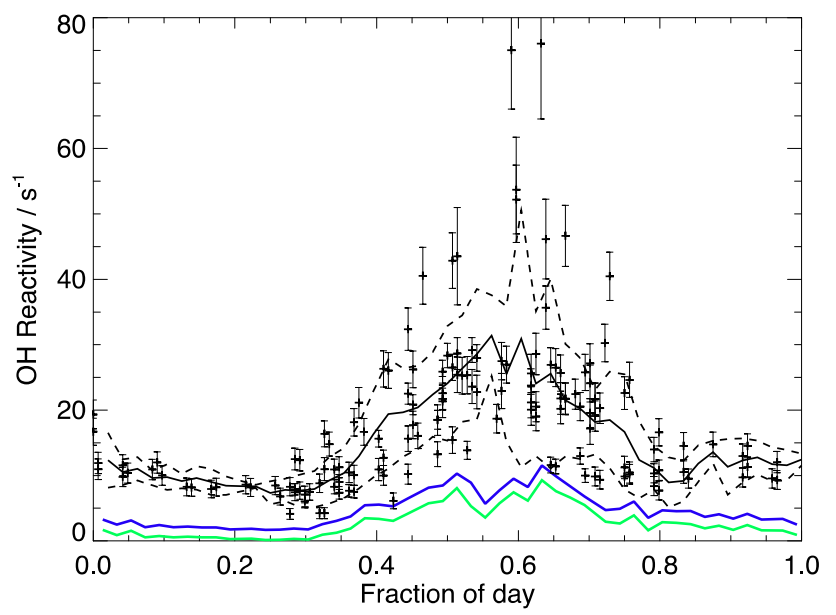

Fig. 4. $\mathrm{OH}$ reactivity observations (black markers), filtered for when supporting observations of major $\mathrm{OH}$ sinks were available, plotted against fraction of local day, with error bars indicating $\pm 1 \sigma$ uncertainty on each observation. The solid black line is the mean diurnal, averaged into $30 \mathrm{~min}$ time bins, with the dashed lines indicating \pm 1 standard deviation. The blue line shows the calculated $\mathrm{OH}$ reactivity from the supporting observations of $\mathrm{OH}$ sinks shown in Fig. 6. The green line is the calculated $\mathrm{OH}$ reactivity from reaction with only the observed isoprene.

profiles of the BVOCs, i.e. the similarity in the observed diurnal trends of isoprene and monoterpenes which can be seen in Fig. 1.

The difference in these gradients can be interpreted in two non-exclusive ways. The first is that the observed gradient is higher than the calculated as there are unmeasured BVOC degradation products, the concentrations of which correlate with isoprene, which act to increase the $\mathrm{OH}$ reactivity associated with the isoprene concentration. The second is that the gradient is higher as there are unmeasured primary emitted compounds that contribute to the $\mathrm{OH}$ reactivity, with emissions that correlate with isoprene's emissions. As the majority of biological emissions are dependent on temperature and sunlight, it is likely that other primary BVOCs would show a similar correlation with the observed $\mathrm{OH}$ reactivity to that shown in Fig. 5. However, limited data overlap between other measured BVOCs, such as the monoterpenes, and $\mathrm{OH}$ reactivity during OP3 makes this comparison impossible to make. As we do not have any knowledge of the abundance or reactivity of unmeasured primary BVOCs during OP3, the influence of the second of the non-exclusive explanations for the missing $\mathrm{OH}$ reactivity stated above is difficult to test. The potential for unmeasured oxidation products of the observed BVOCs to explain a fraction of the missing $\mathrm{OH}$ reactivity, the first of the two possible explanations, can be explored however, as we do have an understanding of the rates of formation and loss of these species. As isoprene was the dominant BVOC, and $\mathrm{OH}$ sink species, measured during OP3, consistent with other studies in similar environments (Kesselmeier

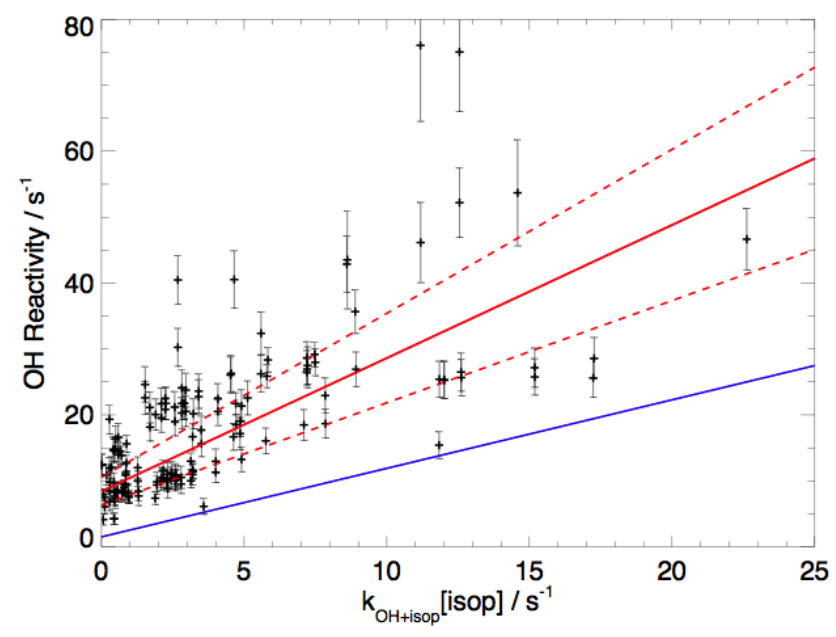

Fig. 5. OH reactivity observations (black points with error bars indicating measurement uncertainties) plotted as a function of the calculated $\mathrm{OH}$ reactivity from isoprene alone for each measurement point. The solid red line is the linear least squares fit to the data, yielding a slope of $2.0 \pm 0.2$, with the dashed red lines showing the $1 \sigma$ uncertainty on the fit. The blue line is the fit to the calculated $\mathrm{OH}$ reactivities based only on the measured $\mathrm{OH}$ sinks (blue line in Fig. 3), with a slope of $1.1 \pm 0.01$.

et al., 2000; Guenther et al., 2006, 2008), the ability of isoprene derived oxidation products to increase the gradient is investigated in the next section.

\section{Conceptual framework}

\subsection{Base simulation}

To investigate the role of the isoprene oxidation products in increasing the gradient in Fig. 5 we use the Dynamically Simple Model of Atmospheric Chemical Complexity (DSMACC) (Emmerson and Evans, 2009; Stone et al., 2010) running the Master Chemical Mechanism (MCM) v3.2 (Saunders et al., 2003; Jenkin et al., 2003). We initially perform some highly stylised experiments, and introduce increasingly more realistic factors.

The initial simulations use the OP 3 average observed concentrations of isoprene (2.5 ppbv) (Jones et al., 2011), $\mathrm{OH}$ $\left(2 \times 10^{6}\right.$ molecule $\mathrm{cm}^{-3}$, Whalley et al., 2011, for one simulation and $2 \times 10^{5}$ molecule $\mathrm{cm}^{-3}$ for another to investigate the impact of $\mathrm{OH}$ concentration) that are kept constant with no photolysis of compounds and a constant zero concentration of $\mathrm{HO}_{2}, \mathrm{O}_{3}$, and $\mathrm{NO}_{\mathrm{x}}$. The concentration of all other compounds are allowed to vary according to the chemistry scheme, with the only source of carbon being the constraining isoprene concentration, and the model is run to a chemical equilibrium where the flux of carbon into the model from the oxidation of isoprene by $\mathrm{OH}$ is balanced by the flux of carbon out of the system as $\mathrm{CO}_{2}$. The top panel in 
Fig. 6 shows the time evolution of the simulated $\mathrm{OH}$ reactivity $\left(=\sum k_{\mathrm{x}+\mathrm{OH}}[\mathrm{X}]\right)$ for the two different $\mathrm{OH}$ concentrations. The lower panel in Fig. 6 shows the simulated total $\mathrm{OH}$ reactivity divided by the simulated system reactivity due to isoprene alone (i.e. in this simulation the only reactive loss for isoprene is reaction with $\mathrm{OH}$ therefore the reactivity due to isoprene $=k_{\mathrm{OH}+\text { isop }}$ [isoprene]), which is a measure of the number of $\mathrm{OH}$ radicals lost per isoprene molecule oxidised and is equivalent to the gradient in Fig. 5. This parameter is a useful tool for investigating the $\mathrm{OH}$ reactivity due to the oxidation products of isoprene and is defined as " $\alpha$ " (Eq. 3).

$\alpha=\frac{\mathrm{OH} \text { reactivity }}{\text { Isoprene } \mathrm{OH} \text { reactivity }}=\frac{\sum k_{\mathrm{OH}+X}[X]}{k_{\mathrm{OH}+\text { isoprene }[\text { isoprene }]}}$

The $\alpha$ value can be considered the flux multiplier for reactivity, i.e. how many $\mathrm{OH}$ radicals are lost throughout the complete oxidation of each VOC molecule emitted, or the accumulated $\mathrm{OH}$ reactivity of an emitted VOC plus all its oxidation products. To help expand upon this, Fig. 6 also shows the calculated $\mathrm{OH}$ reactivities and corresponding $\alpha$ 's for two simple VOCs, ethane and ethene. The mixing ratios of these VOCs are maintained at a constant $2.5 \mathrm{ppbv}$, and the calculated $\mathrm{OH}$ reactivity and $\alpha$ at time zero in Fig. 6 are those for this initial primary VOC concentration. As the simulation integrates forward in time, the accumulation of products from the oxidation of the primary VOC (either ethane, ethene, or isoprene) results in an increase in the calculated total $\mathrm{OH}$ reactivity and calculated $\alpha$, until it reaches a steady state value. In these initial simulations we assume that the primary VOC emission flux is being balanced by its loss by the $\mathrm{OH}$ radical alone, and so for simplicity we can consider the primary VOC flux to be equivalent to the loss flux from the reaction with $\mathrm{OH}$.

In these simple simulations, where there is no physical loss of species or photolysis and the only primary radical present is $\mathrm{OH}$, the steady state $\alpha$ value achieved should equal the number of $\mathrm{OH}$ radical reactions required to oxidise the given VOC and all of its products to $\mathrm{CO}_{2}$ and water vapour. Individual compounds in the oxidation chain react at different rates with $\mathrm{OH}$, their lifetime being related to their reactivity. More reactive compounds are shorter lived and thus are present in lower concentrations. Their concentration and their rate of reaction with $\mathrm{OH}$ on some levels balance out, so at steady state the reactivity reflects the flux of $\mathrm{OH}$ reactive bonds into the system, and as $\mathrm{OH}$ radicals can either react with a VOC by addition to $\mathrm{C}=\mathrm{C}$ double bond or via a hydrogen abstraction reaction, one might expect this steady state $\alpha$ value to reasonably equal the number of $\mathrm{OH}$ attackable bonds available in the primary VOC. This simple reasoning works in the case of ethene, with a steady state $\alpha$ value of $5(4 \times \mathrm{C}-\mathrm{H}+1 \times \mathrm{C}=\mathrm{C})$. This value of $5 \mathrm{can}$ be attributed to 5 reactions during ethene oxidation that each result in the loss of an $\mathrm{OH}$ radical. These reactions are not necessarily all $\mathrm{OH}+\mathrm{C}=\mathrm{C}$ or $\mathrm{OH}+\mathrm{C}-\mathrm{H}$ reactions but the number of available $\mathrm{OH}$ reactions are preserved, for example the formyl radical produced through the reaction of $\mathrm{OH}+\mathrm{HCHO}$ does not react with $\mathrm{OH}$, but with $\mathrm{O}_{2}$ to yield a $\mathrm{CO}$ molecule which subsequently reacts with $\mathrm{OH}$, thus preserving the number of $\mathrm{OH}$ attackable bonds. In the case of ethane, however, the steady state value of $\alpha$ achieved also equals 5, despite the 6 available $\mathrm{C}-\mathrm{H}$ bonds. This reduction in $\alpha$ is due to the breaking of a C-H bond during the decomposition of the alkoxy radical, produced following $\mathrm{OH}$ hydrogen abstraction from the primary VOC and subsequent $\mathrm{RO}_{2}+\mathrm{RO}_{2}$ self reaction. This decomposition reaction breaks a $\mathrm{C}-\mathrm{H}$ bond without the loss of an $\mathrm{OH}$ radical or the preservation of the number of potential $\mathrm{OH}$ attackable bonds, thus reducing $\alpha$. This effect is not seen in the ethene simulation as the ethene alkoxy decomposition preserves the available reactivity. Simulations (not shown) of other small VOCs follow a similar pattern, with small alkenes achieving a steady state $\alpha$ value equal to the number of $\mathrm{OH}$ attackable bonds present in the primary VOC (e.g. propene $\alpha=7$, butene $\alpha=9$ ), and simple alkanes achieving a steady state $\alpha$ value equal to the number of $\mathrm{OH}$ attackable bonds -1 (e.g. propane $\alpha=7$, butane $\alpha=9$ ). Thus the total $\mathrm{OH}$ reactivity of an air mass can be considered (at steady state) to be related to the flux of the primary compound into the system together with a multiplier to reflect the number of $\mathrm{OH}$ attackable bonds associated with the primary emission that need to react. Thus the accumulated $\mathrm{OH}$ reactivity provided by an emitted VOC, i.e. the sum of the $\mathrm{OH}$ reactivity of the primary $\mathrm{VOC}$ and all its oxidation products that react with $\mathrm{OH}$, will provide an effective sink for $\mathrm{OH}$ radicals over a longer time period than the lifetime of the primary VOC, or any individual compound in the oxidation chain. This time over which an emitted compound will provide a sink for $\mathrm{OH}$ is dependent on both the number of $\mathrm{OH}$ attackable bonds in the compound, and hence the number of steps in its oxidation pathway, as well as the reactivity of each compound produced during the oxidation process.

For both isoprene simulations $\alpha$ tends to the value of 10 , which can be attributed to the total number of $\mathrm{OH}$ attackable bonds in the isoprene molecule $(8 \mathrm{C}-\mathrm{H}$ bonds, $2 \mathrm{C}=\mathrm{C}$ bonds). Thus in this case the isoprene flux multiplier for total $\mathrm{OH}$ reactivity is 10 . From a reactivity perspective, the emission of an isoprene molecule into this simple system can therefore be considered as an emission of 10 bonds that ultimately need to react with an $\mathrm{OH}$ radical before the molecule can become $\mathrm{CO}_{2}$ and $\mathrm{H}_{2} \mathrm{O}$ vapour. The $\mathrm{OH}$ concentration used in either case does not impact the final value of $\alpha$, only the time it takes for the system to get to steady state. At higher $\mathrm{OH}$ concentrations the equilibrium value of $\alpha$ is reached more quickly as the time over which the accumulated $\mathrm{OH}$ reactivity from an emitted VOC provides an effective $\mathrm{OH}$ sink is reduced.

The time taken to reach equilibrium in both simulations shown in Fig. 6 is significant (days), however, the $\alpha$ value of 10 is much larger than the observed number of $\mathrm{OH}$ radicals lost per isoprene of 2 (best-fit line, Fig. 5). This suggests that, at least from this simplistic analysis, the question should not 

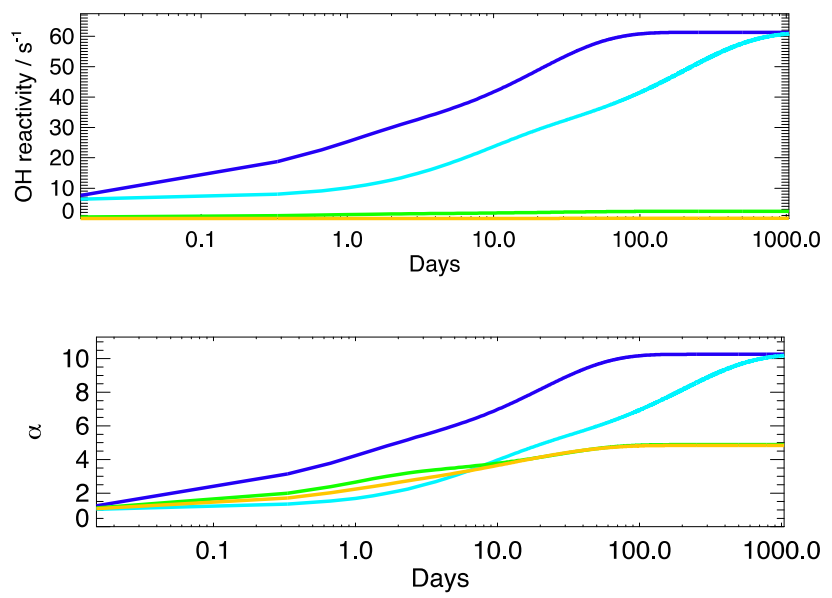

Fig. 6. Time evolution of simulated $\mathrm{OH}$ reactivity (upper plot) and $\alpha$ (OH reactivity divided by the reactivity due to the primary VOC alone) (lower plot) in a model simulation with fixed mixing ratios/concentrations of $2.5 \mathrm{ppbv}$ of ethene (green), ethane (yellow), isoprene, $[\mathrm{OH}]=2 \times 10^{6}$ molecule $\mathrm{cm}^{-3}$ (dark blue) and $2 \times 10^{5}$ molecule $\mathrm{cm}^{-3}$ (pale blue), $\left(\mathrm{NO}_{\mathrm{x}}\right)=\left(\mathrm{HO}_{2}\right)=0$, and no photolysis.

be why the gradient observed in Fig. 5 is as high as 2 but why it is as low as 2 .

In order to investigate the fate of the reactivity generated during the oxidation of isoprene, and how it controls $\mathrm{OH}$ reactivity and the value of $\alpha$, increasingly realistic conditions are now used in the stylised box model.

\subsection{Reactions of Peroxides}

In the simulations in Fig. 6 the $\mathrm{HO}_{2}$ concentration was maintained at zero. A constant $\mathrm{HO}_{2}$ concentration of $2.5 \times 10^{8}$ molecule $\mathrm{cm}^{-3}$ (10 pptv) is now introduced into the simulation together with an $\mathrm{OH}$ concentration of $2 \times 10^{6}$ molecule $\mathrm{cm}^{-3}$ (see Fig. 7). Again the $\mathrm{HO}_{2}$ concentration used is the average noontime concentration observed during the OP3 campaign (Whalley et al., 2011). In this case the final calculated steady state reactivity is higher than in the equivalent simulation without $\mathrm{HO}_{2}$, with a steady state value of $\alpha=11.4$. This increase in reactivity is due to the production of peroxides, which can recycle their parent peroxy radical upon reaction with $\mathrm{OH}$. Thus an $\mathrm{OH}$ is destroyed without effectively destroying one of the originally emitted isoprene bonds, therefore increasing the overall reactivity.

$\mathrm{RO}_{2}+\mathrm{HO}_{2} \rightarrow \mathrm{ROOH}$

$\mathrm{ROOH}+\mathrm{OH} \rightarrow \mathrm{RO}_{2}$

Thus this peroxide recycling mechanism creates a catalytic route to $\mathrm{OH}$ destruction; and the total reactivity of the system can be increased beyond the reactivity available from the bonds in the isoprene molecule alone.
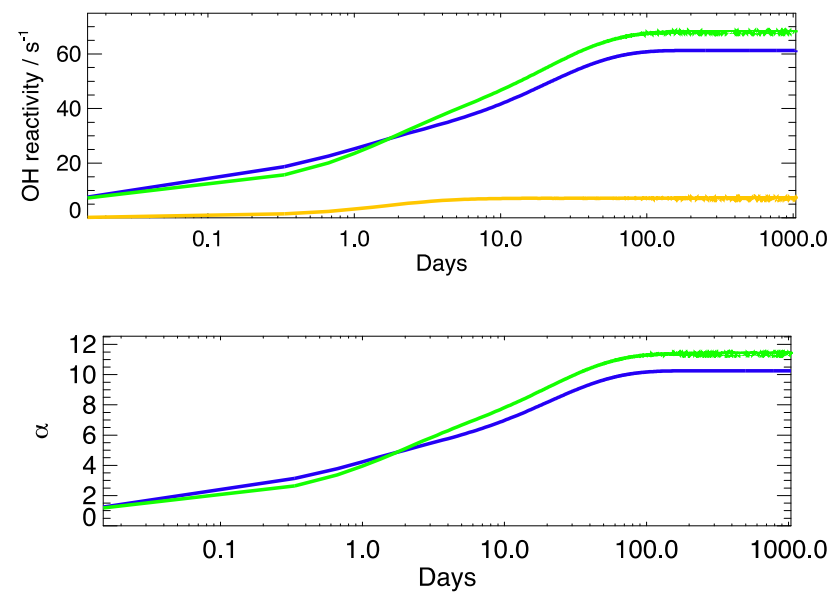

Fig. 7. Evolution of total $\mathrm{OH}$ reactivity and $\alpha$ in the base simulation with constant zero $\mathrm{HO}_{2}$ concentration (dark blue) and a simulation with a $\mathrm{HO}_{2}$ concentration of $2.5 \times 10^{8}$ molecule $\mathrm{cm}^{-3}$ (green). This increase in both reactivity and $\alpha$ is due to the formation of peroxides that can catalytically destroy $\mathrm{OH}$ as described in the text. The reactivity due to the peroxides alone is shown in the yellow trace.

\subsection{Photolysis and other oxidants}

The evolution of the system's $\mathrm{OH}$ reactivity is also found to be impacted by the introduction of photolysis and oxidants other than $\mathrm{OH}$ into the modelling system. Figure 8 shows the impact of both other oxidants and photolysis on the system. For the photolysis we use a constant photolysis rate calculated at the appropriate rates for a solar zenith angle of $45^{\circ}$, and an $\mathrm{O}_{3}$ column of 260 Dobson units. This reduces the reactivity in the system and $\alpha$ by around $20 \%$. This reduction is due to the breaking of certain bonds within the isoprene molecule or and/or its oxidation products by photolysis rather than through reaction with $\mathrm{OH}$, in particular those of formaldehyde (a significant product of isoprene oxidation, Finlayson-Pitts and Pitts, 1986).

Oxidants other than $\mathrm{OH}$ have a similar but smaller impact on reactivity (Fig. 8). For example $\mathrm{O}_{3}$ at constant concentrations of 10 and $100 \mathrm{ppbv}$ reduces the reactivity by 0.34 and $2.44 \%$ respectively. In order to make a consistent comparison, the model simulation shown in Fig. 8 has had the reaction of $\mathrm{O}_{3}$ with isoprene switched off so that the impact is on the secondary products alone. Otherwise the reaction produced enhanced concentrations of secondary products as it increased the flux of isoprene. $\mathrm{NO}_{3}$ (not shown) has a similar impact to $\mathrm{O}_{3}$ but at the concentrations calculated for the OP3 site the changes are insignificant.

From these investigations of this physically simplified chemical system we conclude that to a first order the steady state reactivity is related to the rate of oxidation of isoprene by $\mathrm{OH}$ multiplied by the number of $\mathrm{OH}$ attackable bonds (10). Second-order effects then include the increase in $\mathrm{OH}$ reactivity due to peroxide recycling, and a decrease in $\mathrm{OH}$ 

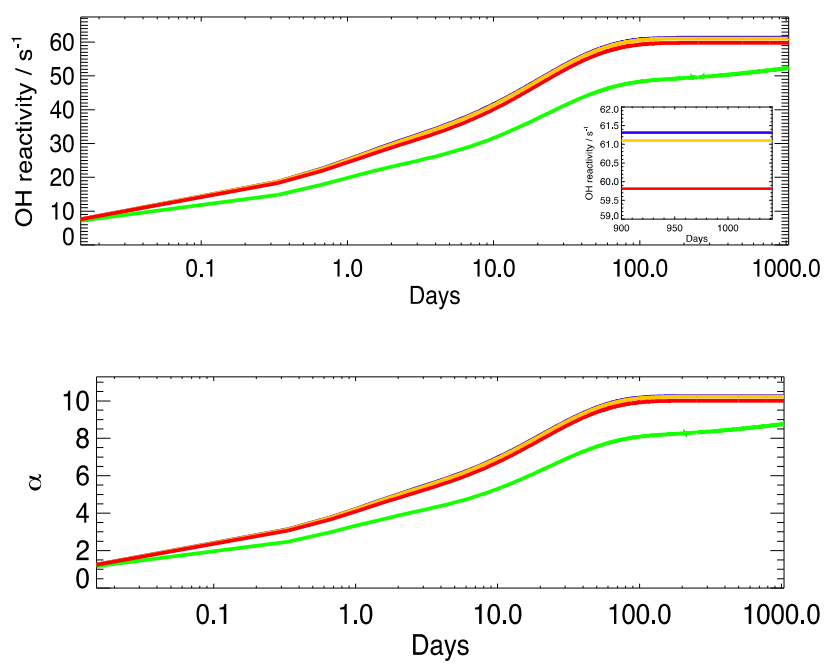

Fig. 8. Evolution of total $\mathrm{OH}$ reactivity and $\alpha$ in the base simulation (dark blue, hidden beneath red and yellow) compared with a simulation using photolysis rates calculated for a solar zenith angle of $45^{\circ}$ (green), resulting in a value of $j\left(\mathrm{O}^{1} \mathrm{D}\right)$ of approximately $2.5 \times 10^{5} \mathrm{~s}^{-1}$. The effect of other oxidants on the calculated $\mathrm{OH}$ reactivity and $\alpha$ are shown using simulations that include $\mathrm{O}_{3}$ mixing ratios of $10 \mathrm{ppbv}$ (yellow) and $100 \mathrm{ppbv}$ (red). The inset plot shows the spread of the calculated reactivities with different $\mathrm{O}_{3}$ mixing ratios at steady state.

reactivity due to photolysis and other oxidants. Section 4.4 investigates how physical loss of compounds impacts these conclusions.

\subsection{Physical loss}

For a simple box, the physical loss of chemical species, whether from dilution into a lower background or the deposition of species to the surface or the canopy, or the formation of aerosol, can be considered to be a first-order loss process. For simplicity we give all unconstrained compounds the same physical loss lifetime. Figure 9 shows the impact of physical lifetimes of 12, 24, 48 and $72 \mathrm{~h}$ (the range is based on studies of deposition of oxygenated VOCs to forest canopies; Hall et al., 1999; Karl et al., 2004). This significantly reduces the reactivity of the system as isoprene degradation compounds are physically removed before they can impact the $\mathrm{OH}$ reactivity, either directly or through the production of further oxidation products. As the physical loss rate increases the oxidation products are increasingly rapidly removed from the system and the $\alpha$ of the system tends to 1 , which is the value of the reactivity for isoprene alone. The timescale to reach steady state is significantly reduced by the introduction of this physical loss. The time to generate $75 \%$ of the steady state oxidation product reactivity (i.e. $50 \%$ of the steady state reactivity not including the reactivity due to reaction with isoprene itself) is over 20 days without physical
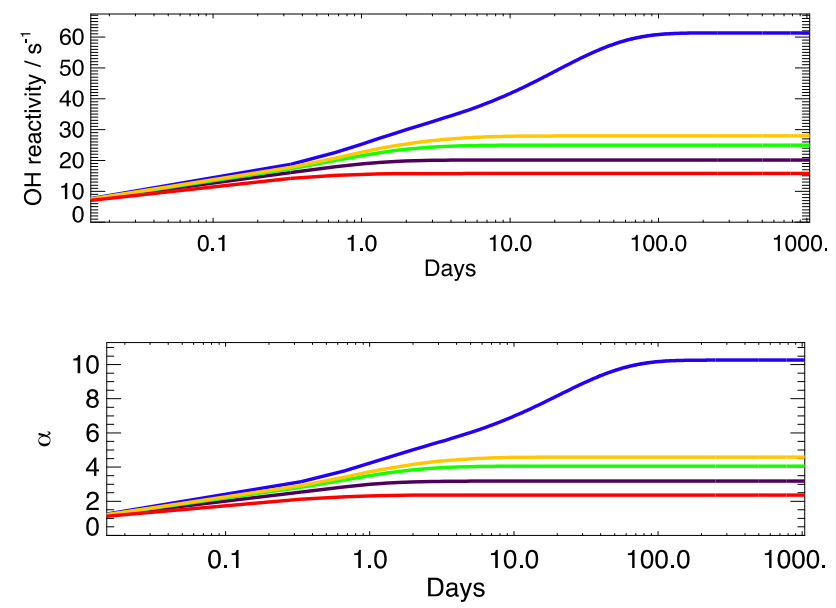

Fig. 9. Evolution of total $\mathrm{OH}$ reactivity and $\alpha$ in the base simulation (dark blue) compared with simulations containing a rate of loss of all non-constrained species to physical processes equivalent to a lifetime of 12 (red), 24 (purple), 48 (green) and $72 \mathrm{~h}$ (yellow).

loss but this becomes $12 \mathrm{~h}$ with a $72 \mathrm{~h}$ lifetime and less than $8 \mathrm{~h}$ for the $12 \mathrm{~h}$ lifetime case.

These reductions in reactivity are much larger than was seen from the introduction of other oxidants or photolysis (Fig. 8), due to the removal of molecules that have multiple potential $\mathrm{OH}$ reaction sites. Thus, physical loss represents a potent mechanism to remove reactivity from the model.

\subsection{Impact of $\mathrm{OH}$ concentration}

The analysis described in Sect. 4.1 (no physical loss) showed no relationship between the $\mathrm{OH}$ concentration and the calculated steady state value of total $\mathrm{OH}$ reactivity (Fig. 6), as changing the $\mathrm{OH}$ concentration does not change the number of bonds that need to be oxidised. However, with the inclusion of the physical loss process the system does become sensitive to the $\mathrm{OH}$ concentration. A competition is set up between the rate at which the oxidation products are produced and the rate at which they are removed from the system by physical loss. Figure 10 shows the effect of $\mathrm{OH}$ concentration on the calculated steady state reactivity and the value of $\alpha$ achieved. In these more realistic simulations we include photolysis, peroxide formation, $\mathrm{O}_{3}$ and $\mathrm{NO}_{\mathrm{x}}$, and a lifetime with respect to physical loss of model-calculated species of $24 \mathrm{~h}$ (i.e. a first-order loss rate constant of $1.15 \times 10^{-5} \mathrm{~s}^{-1}$ applied to all species). As the $\mathrm{OH}$ concentration is increased so does the reactivity and the $\alpha$ value. Isoprene degradation products are thus produced at a faster rate compared to their physical loss and so their concentrations increase leading to the total $\mathrm{OH}$ reactivity increasing at a faster rate. 

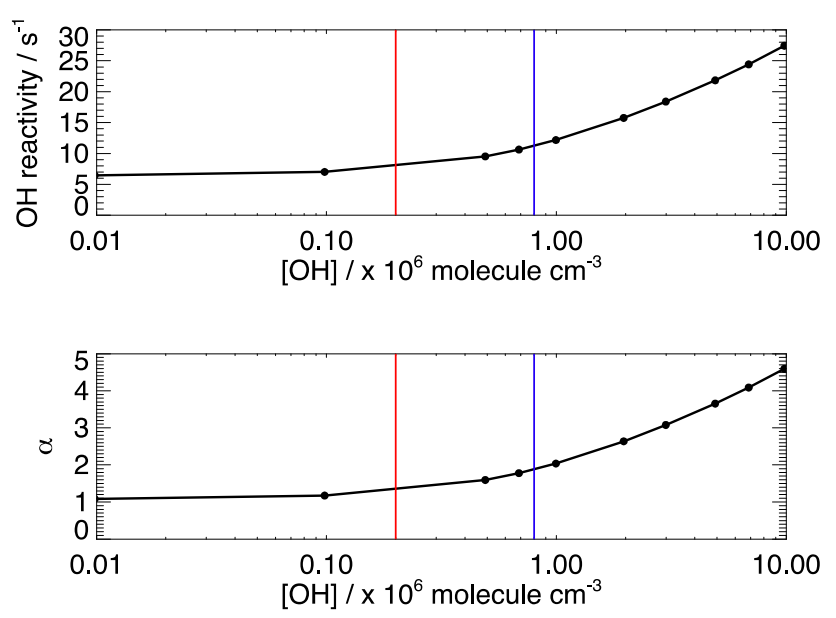

Fig. 10. Dependence of calculated steady state $\mathrm{OH}$ reactivity (top panel) and $\alpha$ (lower panel) on $\mathrm{OH}$ concentration when the physical removal rate within the model is equivalent to a $24 \mathrm{~h}$ lifetime. The vertical lines represent daily mean $\mathrm{OH}$ concentration during OP3 $\left(8 \times 10^{5}\right.$ molecule $\mathrm{cm}^{-3}$, Whalley et al. 2011) (blue), and daily mean $\mathrm{OH}$ concentration calculated by the MCM v3.2 chemistry scheme $\left(2 \times 10^{5}\right.$ molecule $\left.\mathrm{cm}^{-3}\right)$ (red line). The MCM model calculations and the impact of the $\mathrm{OH}$ concentrations is discussed further in Sect. 6.

\subsection{Summary}

This very simple modelling has provided a framework to understand $\mathrm{OH}$ reactivity. At a zeroth order, $\mathrm{OH}$ reactivity can be considered as a quantity related to the number of $\mathrm{OH}$ attackable bonds in a molecule and the flux of that molecule. First-order chemical processes can act to increase (peroxide cycling) or decrease the reactivity (photolysis and other oxidants) but these processes seem to have relatively small impacts $(\leq 20 \%)$. However, physical processes can significantly reduce total $\mathrm{OH}$ reactivity by removing bonds permanently from the system. Within a system with physical loss, increases in the $\mathrm{OH}$ concentrations tend to increase reactivity as it increases the rate at which oxidation products are produced.

After constructing this framework for considering $\mathrm{OH}$ reactivity the following sections attempt to explain the $\mathrm{OH}$ reactivity observations described in Sect. 3 .

\section{Observationally constrained model simulations}

To investigate the mechanisms controlling $\mathrm{OH}$ reactivity during OP3 (Sect. 3), the $\mathrm{OH}$ reactivity observations were simulated using the box model described in Sect. 4.1. This model was constrained by the observed diurnal cycle in isoprene, monoterpenes, $\mathrm{NO}_{2}, \mathrm{O}_{3}, \mathrm{CO}$ and the other observed hydrocarbons shown in Fig. 1, and utilised the MCM v3.2 oxidation schemes for all of the constraining species. The $\mathrm{OH}$ concentration was similarly constrained to the average observed diurnal reported in Whalley et al. (2011). The model is run forward in time using the diurnally varying concentrations of the observed compounds and with diurnally varying photolysis rates, calculated using TUV (Madronich, 1998) scaled to the observed $j\left(\mathrm{O}^{1} \mathrm{D}\right)$, until a steady state is reached (i.e. the concentration of all compounds in day $i$ is the same (within $1 \%$ ) of the compounds in day $i-1)$. As the rate of the physical loss of unmeasured species, via processes such as mixing, transport, deposition and SOA formation, is poorly constrained, a single first-order loss rate has been used for all unconstrained species in the chemistry scheme giving these compounds a physical lifetime of $24 \mathrm{~h}$. This is equivalent of a mixing out of the canopy into the boundary layer to a zero background concentration, and/or a deposition to a surface (the ground, the canopy or aerosol).

Figure 11 shows the modelled $\mathrm{OH}$ reactivity compared with the observations. The observed $\mathrm{OH}$ reactivity during the nighttime is reproduced to within the measurement uncertainty. The modelled daytime $\mathrm{OH}$ reactivity, however, significantly underestimates the observations. This again is consistent with the previous studies (Kovacs et al., 2003; Di Carlo et al., 2004; Sinha et al., 2008, 2010; Hofzumahaus et al., 2009; Lou et al., 2010).

The model is capable of producing $\mathrm{OH}$ reactivity that is much closer to observed daytime values when it is constrained to the diurnal concentration profiles of $\mathrm{OH}$ and isoprene, each increased by one standard deviation of their observations (dashed red lines in Fig. 11 show calculated $\mathrm{OH}$ reactivity using \pm 1 standard deviation of $\mathrm{OH}$ and isoprene concentration). Given the short lifetime of isoprene (approximately $1.3 \mathrm{~h}$ at local noon) and the significantly longer effective time over which the accumulated $\mathrm{OH}$ reactivity produced from the oxidation of an isoprene molecule provides an $\mathrm{OH}$ sink (longer than the physical lifetime of 1 day) it is not unreasonable to expect some mismatch (magnitude and timing) between the concentrations of isoprene and observed $\mathrm{OH}$ reactivity. As the OP3 observations were made on a ridge in a clearing in the forest, it seems likely that the source of any isoprene oxidation products that contribute to the observed $\mathrm{OH}$ reactivity may not be the products of isoprene being sampled at the site, but from the oxidation of isoprene introduced within the forest canopy some distance from the site. The concentration of observed isoprene on the ridge, although likely following the same diurnal pattern as that in the surrounding forest, is probably lower than the isoprene experienced earlier by the air mass within the forest canopy, which is the isoprene defining any observed $\mathrm{OH}$ reactivity from isoprene oxidation products. In contrast, during the nighttime, when the measurement site was more isolated from the surrounding forest (Sect. 3), the model does a much better job of reproducing the observed $\mathrm{OH}$ reactivity from the measured BVOCs. 




Fig. 11. OH reactivity observations (black markers) plotted as a diurnal, with error bars indicating $\pm 1 \sigma$ uncertainty on each observation. The solid black line is the mean diurnal profile, averaged into 30 min time bins, with the dashed black lines indicating \pm 1 standard deviation within that $30 \mathrm{~min}$ bin. The solid red line shows the modelled $\mathrm{OH}$ reactivity using the mean diurnal concentrations of the measured isoprene, $\mathrm{OH}$ and monoterpenes, the other measured species shown in Fig. 6 constrained to their mean value, and also using the steady state concentrations of the oxidation products of these constraining species, calculated by the MCM v3.2 chemistry scheme. The dashed red lines are the modelled $\mathrm{OH}$ reactivities constraining to \pm 1 standard deviation of the observed $\mathrm{OH}$ and isoprene concentrations, with all other constraining species kept at the same concentrations as the solid red line simulation.

\section{Processes determining $\mathrm{OH}$ reactivity in the rainforest}

The idealised simulations described in Sect. 4 identified various processes that impact the magnitude of the $\mathrm{OH}$ reactivity due to the oxidation products of the primary emitted VOCs. Using the observationally constrained model described in Sect. 5 , the sensitivity of the calculated $\mathrm{OH}$ reactivity to these processes is now investigated in a set of more realistic simulations.

\subsection{Sensitivity to $\mathrm{OH}$ concentration}

Previous modelling studies of forested environments with high biogenic VOC emissions have significantly underestimated the observed $\mathrm{OH}$ concentrations (Tan et al., 2001; Kubistin et al., 2010; Hofzumahaus et al., 2009; Whalley et al., 2011; Stone et al., 2011). A simulation with unconstrained OH for OP3 exhibits a similar result (not shown but consistent with Whalley et al., 2011). The calculated daily maximum $\mathrm{OH}$ concentration peaks at approximately $5 \times 10^{5}$ molecule $\mathrm{cm}^{-3}$ compared with the observed $2 \times 10^{6}$ molecule $\mathrm{cm}^{-3}$ and the calculated daily mean $\mathrm{OH}$ concentration was $2 \times 10^{5}$ molecule $\mathrm{cm}^{-3}$ compared to the observed $8 \times 10^{5}$ molecule $\mathrm{cm}^{-3}$. Figure 12 shows the impact of the lower modelled $\mathrm{OH}$ on the calculated reactivity. The $\mathrm{OH}$

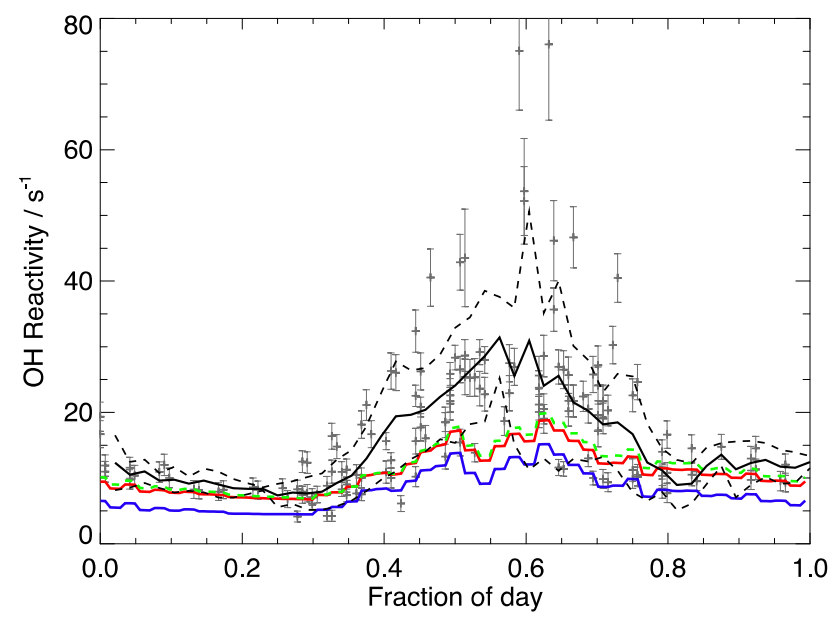

Fig. 12. OH reactivity observations (black markers) plotted as an average diurnal, with error bars indicating $\pm 1 \sigma$ uncertainty on each observation. The solid black line is the mean diurnal profile, averaged into $30 \mathrm{~min}$ time bins, with the dashed black lines indicating \pm 1 standard deviation within that $30 \mathrm{~min}$ bin. The solid red line shows the modelled $\mathrm{OH}$ reactivity from the base model simulation (described in Sect. 5) with $\mathrm{OH}$ concentrations constrained to their mean observed value. The blue line shows the calculated $\mathrm{OH}$ reactivity in a model simulation where the $\mathrm{OH}$ concentration has been calculated by the MCM v3.2 chemistry scheme. The green dashed line shows the calculated $\mathrm{OH}$ reactivity using the same constraints as the base model simulation (red line), but using the MCM v3.1 chemistry scheme (Sect. 6.2)

reactivity drops by $20 \%$, roughly consistent with the change in going from $8 \times 10^{5}$ to $2 \times 10^{5}$ molecule $\mathrm{cm}^{-3}$ as was shown in Fig. 10.

Thus, simulations of $\mathrm{OH}$ reactivity which use calculated rather than observed $\mathrm{OH}$ concentrations are likely to underestimate the reactivity produced from unmeasured isoprene oxidation products, as the modelled $\mathrm{OH}$ concentration is known to significantly underestimate the measured value. However, this impact is small compared to the magnitude of the missing reactivity.

\subsection{Sensitivity to other oxidants, photolysis, and isoprene oxidation mechanism}

In Sect. 4.3 oxidants other than $\mathrm{OH}$, and photolysis were shown to be able to reduce the $\mathrm{OH}$ reactivity calculated by the model. However, simulations run under OP3 conditions show that the calculated reactivity has little or no sensitivity to these parameters $(<10 \%)$. This reflects the physical loss timescale imposed on the model (lifetime with respect to physical loss of $24 \mathrm{~h}$ ) that removes reactivity significantly faster than other oxidants or photolysis are able to.

The sensitivity of the calculated $\mathrm{OH}$ reactivity to the isoprene oxidation mechanism used in the model has also been investigated. A simulation using the same constraints as the base simulation, described in Sect. 5, but using the 
MCM v3.1 chemistry scheme is shown in Fig. 12. MCM v3.1 does not contain the updates to the isoprene degradation chemistry, including the inclusion of revised chemistry for isoprene-derived hydroperoxides and nitrates, which are present in v3.2. For more information on the difference between the chemistry schemes visit http://mcm.leeds.ac.uk/ $\mathrm{MCM} /$. This simulation shows a small $(<10 \%)$ increase in calculated $\mathrm{OH}$ reactivity in the later half of the day, due to an increase in the reactivity from peroxides, which have a higher production rate in the MCM v3.1 chemistry scheme compared to v3.2. This simulation implies that when the model concentration of $\mathrm{OH}$ and the physical removal rate of all calculated species are constrained, the calculated $\mathrm{OH}$ reactivity is relatively insensitive to the specific VOC oxidation mechanism used. The effect of the isoprene oxidation mechanism used would, however, be expected to show a larger influence on the calculated $\mathrm{OH}$ reactivity if the $\mathrm{OH}$ concentration were left unconstrained, due to the large differences in $\mathrm{OH}$ concentration calculated by different isoprene oxidation mechanisms (Lelieveld et al., 2008; Paulot et al., 2009a, b; Peeters et al., 2009). Differences in the true physical removal rates of the oxidation products generated by different chemical mechanisms will also likely impact the calculated $\mathrm{OH}$ reactivity (Sect. 6.3), however, these physical removal parameters are highly uncertain.

\subsection{Physical loss}

It was shown in Sect. 4 that the physical loss represented a significant sink for $\mathrm{OH}$ reactivity. Figure 13 shows the impact of changing the physical loss lifetime from 1 to $96 \mathrm{~h}$. Within this range, the model calculates a wide range of $\mathrm{OH}$ reactivity, and is within the uncertainty range of the observed values.

The value of this physical loss parameter is difficult to determine experimentally, and our treatment of this process, via a uniform loss rate for all compounds, is simplistic. However, it does point towards the large sensitivity of modelled $\mathrm{OH}$ reactivity towards this parameter. More complex representations of canopy mixing (such as that used by Wolfe and Thornton, 2011) may be one approach to better constrain this parameter. Uptake to aerosols and the deposition of species to the forest soils and canopy through wet and dry processes is complex and poorly understood. It is thought that wet deposition is a major loss route for these oxygenated VOCs (OVOCs), due to their high solubility (Hall et al., 1999; Reeves and Penkett, 2003; Matsunaga et al., 2007). However, the solubility of many hydroperoxides and other oxygenated organics is extremely uncertain and known to cover a wide range, with the measured Henry's law constants for methyl hydroperoxide and peroxyacetic acid being 2-3 orders of magnitude lower than that for $\mathrm{H}_{2} \mathrm{O}_{2}$ (Lind and Kok, 1986). Observations of OVOC deposition velocities are sparse, with only a handful reported for forested regions (Hall and Claiborn, 1997; Valverde-Canossa et al.,

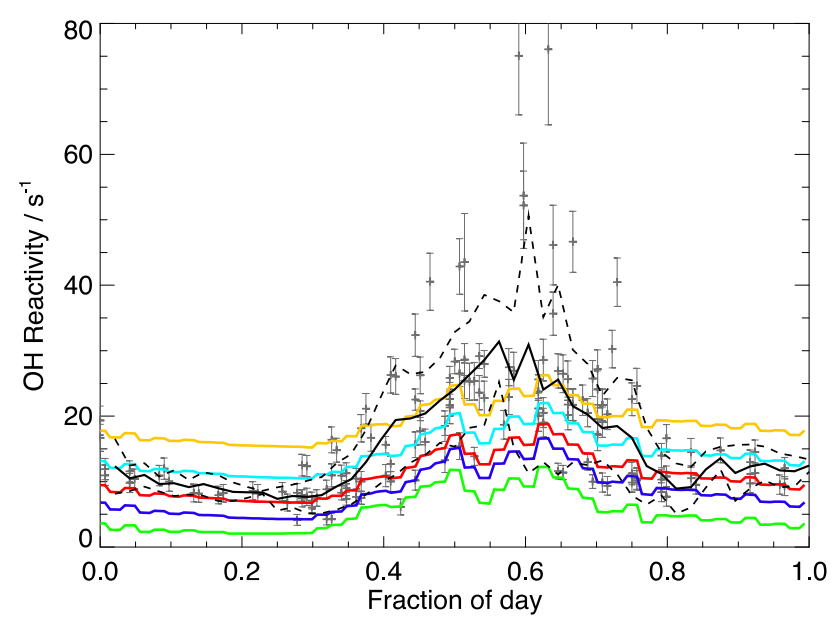

Fig. 13. Diurnal variation of the observed $\mathrm{OH}$ reactivity (black points) and a set of model simulations with different first-order loss rates to represent the loss of model generated species to physical processes. The lifetime of species with respect to this first-order loss are 1 (green), 12 (dark blue), 24 (red), 48 (pale blue), and $96 \mathrm{~h}$ (yellow).

2006; Hall et al., 1999; Karl et al., 2004; Kuhn et al., 2002). An observation of the deposition velocity of the sum of MVK and MACR in a tropical rainforest by Karl et al. (2004) found velocities of $0.45 \pm 0.15 \mathrm{~cm} \mathrm{~s}^{-1}$. Using an average observed boundary layer height during OP3 of $800 \mathrm{~m}$ (Hewitt et al., 2010) this is equivalent to a lifetime of approximately 2 days.

The removal of species out of the forest canopy and into the boundary layer via mixing will also play a key role in this physical removal term. Complex topography results in complex local meteorology at the Bukit Atur site, with several studies identifying very different meteorological conditions between the day and the night (as discussed in Sects. 2 and 3) (Pearson et al., 2010; Pike et al., 2010; Pugh et al., 2010). Given the local meteorology, it seems unlikely that the mixing lifetime of compounds in the canopy remained constant throughout the day, and instead would have displayed significant diurnal variability.

Although deposition and mixing have the same impact on the modelled $\mathrm{OH}$ reactivity, on a global scale their impact is very different. On a global scale mixing conserves the accumulated $\mathrm{OH}$ reactivity from an emitted molecule, it is just moved from one location to another, whereas deposition removes $\mathrm{OH}$ reactivity. Considering $\mathrm{OH}$ reactivity as a tracer in itself poses some interesting questions for a global perspective. What is the global budget for the total $\mathrm{OH}$ reactivity of isoprene or other hydrocarbons? The $500 \mathrm{Tg} \mathrm{C} \mathrm{yr}^{-1}$ of isoprene emitted each year is equivalent to $\sim 1.5 \mathrm{~T} \mathrm{~mol}$ isoprene $\mathrm{yr}^{-1}$ or $15 \mathrm{~T} \mathrm{~mol} \mathrm{OH}$ attackable bonds per year. What fraction of those bonds are removed by reaction with $\mathrm{OH}, \mathrm{O}_{3}$, $\mathrm{NO}_{3}$, or deposited? Globally, how much reactivity is created by peroxide cycling? Do models appropriately conserve reactivity through their chemical mechanism? Considering such 
questions on a global or regional basis may provide insights into the mechanisms controlling the global $\mathrm{OH}$ concentrations.

\section{Missing $\mathrm{OH}$ reactivity owing to primary emitted species}

Given the variability in the isoprene concentration, and the mismatch between the lifetime of isoprene and the timescale over which the accumulated $\mathrm{OH}$ reactivity generated by the subsequent isoprene oxidation steps provides a sink for $\mathrm{OH}$, uncertainties in the physical loss rates and in the photolysis environment, it is not clear that the underestimate of reactivity (as shown in Fig. 11) really reflects a missing process. However, the existence of a missing primary emitted compound cannot be ruled out. At noon the model calculates a reactivity of $\sim 15 \mathrm{~s}^{-1}$, missing $\sim 7 \mathrm{~s}^{-1}$ compared to the observations. This is equivalent to $\sim 3$ ppbv of isoprene ignoring its degradation products or $\sim 1.5 \mathrm{ppbv}$ if degradation products are included (using the observed $2 \mathrm{OH}$ radicals lost per isoprene from Fig. 5). This value of $1.5 \mathrm{ppbv}$ is equivalent to half the measured isoprene concentration. If this missing emission were occurring globally it would provide a significant global source of reactive carbon to the atmosphere. If the missing primary sink was a monoterpene or larger terpenoid then the required concentration would be less, reflecting the larger number of carbon bonds per molecule.

Identifying missing reactive carbon in the atmosphere can be informed to some extent by considering the "gaps" in capability left by existing instrumentation. The OP3 project used three instruments to determine reactive gas phase carbon: a GC-FID, a GC-MS and a PTR-MS (Jones et al., 2011; Langford et al., 2010). This is typical of many largescale process studies. Taking each in turn helps identify what species types may evade detection and comprise an undetected carbon sink. GC-FID in this experiment covered a carbon range of approximately $\mathrm{C} 2$ to $\mathrm{C} 12$ using two different GC columns. Whilst identification of higher hydrocarbons (meaning $\mathrm{C}$ and $\mathrm{H}$ containing) is difficult with just FID, the presence of such species would be seen in the form of unknown peaks. The FID acts simply by burning carbon, so any compound that could pass through the column would create a response. A similar situation would arise with GC-MS, in this instance if operated in full scan mode. Sample collection on adsorbent traps adds a further degree of constraint and selectivity but in general terms is amenable to all gas phase $\mathrm{CH}$ species and many $\mathrm{CHO}$ compounds. Some species undergo chemical transformation upon sampling but the carbon is typically conserved, so a missing sink would be detected but would perhaps be misidentified. The combination of both methods provides a strong indication that a missing sink is unlikely to be a simple hydrocarbon. Both techniques also resolve some more polar species, as does the PTR-MS method. $\mathrm{GC}$ techniques are generally good at resolving ketones and aldehydes but become increasingly unreliable as functionality and polarity increases. Acids and peroxides for example would probably escape detection by chromatographic methods unless derivatisation was used. PTR-MS provides a further useful constraint. In full scan it essentially detects all organic compounds with a suitable proton affinity. This spans basic hydrocarbons and most oxygenated species. Similar to FID a missing species would be seen as an unusual signal even if the exact identification of the species could not be made. The simple inlets to PTR-MS make semi-volatile species reasonable to sample. For complex mixtures of isobaric species such as sesquiterpenes the simple common ion generated by PTR should help detection - but these species are not seen in any abundance. For a more comprehensive review of VOC measurement techniques and their capabilities and limitations see Koppman (2007).

Green leaf volatiles (GLVs) form a subset of biogenic emissions, being oxygenated hydrocarbons produced from the biochemical conversion of linoleic and linolenic acid within plant cells. GLVs are not released from all vegetation types, and are most commonly associated with wheat, oilseed rape, grape and birch trees. These oxygenated species are generally released when mechanical damage occurs to leaves, by either cutting, abrasion or the grazing of animals. Detection of common GLVs, such as cis-3-hexen-1-ol and cis-3-hexenyl acetate, is possible by adsorption tubes, GCMS methods and also by PTR-MS (albeit with some potential for isobaric interference amongst each other). During OP3 neither the GC nor PTR-MS made a positive identification of these species, and it is therefore assumed that GLVs were not present in any significant concentration to account for the "missing" OH sink.

Therefore, overall there is only a relatively small subset of gas phase compound classes that would evade detection when this combination of instruments is used in full scan modes. Multifunctional species are one possibility, as are difficult to ionise compound classes such as organic peroxides, or difficult to handle species such as acids. Whilst a process of elimination does not necessarily get close to finding the exact species needed to close budgets, it does suggest where attention could reasonably be focused in future instrument development.

\section{Make-up of unmeasured carbon species}

The observations made during this project do not enable the budget for $\mathrm{OH}$ reactivity to be closed, nor does the box modelling provide a definitive explanation for the source of the missing reactivity. However, the modelling can be used to identify those compounds that should be measured in future studies to enable a better constraint on this problem. Figure 14 illustrates the fractional contribution of different compounds (and compound types) to the noontime $\mathrm{OH}$ reactivity calculated by the model (solid red line in Fig. 11). 


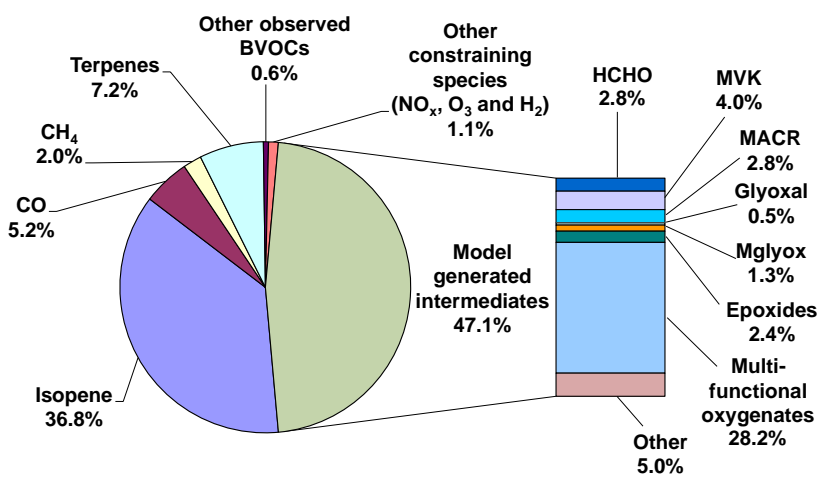

Fig. 14. Percentage contributions towards the noontime calculated $\mathrm{OH}$ reactivity using a $24 \mathrm{~h}$ lifetime with respect to physical loss of model generated species (solid red line in Fig. 11). The largest single contribution to the calculated $\mathrm{OH}$ reactivity comes from isoprene, however the model calculated intermediates contribute a larger fraction toward the observed $\mathrm{OH}$ sink than isoprene and the observed terpenes combined.

Isoprene accounts for $\sim 37 \%$ of the reactivity, with the remaining observed constraining species $\left(\mathrm{CH}_{4}, \mathrm{CO}, \mathrm{H}_{2}, \mathrm{NO}_{\mathrm{x}}\right.$, $\mathrm{O}_{3}$ and observed BVOCs including terpenes) accounting for $16 \%$. Unmeasured degradation products account for almost $50 \%$ of the calculated reactivity. This fraction consists of over 900 different oxygenated compounds, with the largest fraction (over $30 \%$ of the total calculated reactivity) coming from multifunctional oxygenates such as methyl-glyoxal and epoxides formed during isoprene oxidation, as well as numerous aldehydes and ketones.

Although current technology allows for some of these to be measured (for example MVK, MACR, HCHO and some peroxides) the majority of the multifunctional model generated intermediates are not readily amenable to current experimental techniques. However, if the reactivity budget is to be closed, these more complex organic compounds need to be measured.

\section{Conclusions}

Observations of $\mathrm{OH}$ reactivity were made for a period of 12 days during April 2008 in a tropical rainforest in Borneo. The maximum observed $\mathrm{OH}$ reactivity was $83.6 \pm 26.0 \mathrm{~s}^{-1}$ with the diurnally averaged noontime maximum being $29.1 \pm$ $8.5 \mathrm{~s}^{-1}$. OH reactivity calculated using the observed sinks peaks at approximately $18 \mathrm{~s}^{-1}$, significantly less than the observations and consistent with previous studies in similar environments. This calculated reactivity is dominated by isoprene (37\% at noon), with the diurnal trend in observed reactivity following that of the isoprene concentration.

A series of idealised model simulations have provided a framework in which to investigate $\mathrm{OH}$ reactivity, where to a first order the flux of total $\mathrm{OH}$ reactivity into the system was equivalent to the flux of isoprene multiplied by a factor to represent the number of $\mathrm{OH}$ attackable bonds per molecule (10). These idealised simulations show that the time period over which the accumulated $\mathrm{OH}$ reactivity from an emitted molecule into the system is significantly longer than the lifetime of the initial molecule and depends on the lifetimes of intermediate species. The $\mathrm{OH}$ reactivity of a system thus depends not only on the rate of emission of primary sink species, but also on the competition between $\mathrm{OH}$ and other processes that remove the reactivity produced throughout the entire oxidation chain. Physical loss is identified as the dominant process that changed the reactivity calculated with the $\mathrm{OH}$ concentration, other oxidants and peroxide cycling playing a smaller role.

A constrained box model substantially underestimates the observations of $\mathrm{OH}$ reactivity. There is substantial variability in the observations of isoprene and $\mathrm{OH}$ and increasing the concentrations of these compounds within the model by one standard deviation of their variability greatly improves agreement between calculated and observed $\mathrm{OH}$ reactivity. Given the mismatch between the lifetime of isoprene and the effective time over which the accumulated $\mathrm{OH}$ reactivity from an emitted isoprene molecule persists (by roughly an order of magnitude) it is not obvious that the observations themselves provide the appropriate information for the modelling study. The model is particularly sensitive to the physical loss (deposition or mixing) parameterisation used, which highlights the need for improved constraints on these key processes. We find that our modelling provides substantial uncertainties in the reactivity calculated, which makes the need for a missing primary emitted compound less pressing compared with previous studies. If a missing compound were invoked to explain all the difference between the modelled and measured $\mathrm{OH}$ reactivity it would need to provide a carbon input equivalent to a $50 \%$ increase in the isoprene concentration.

The supporting measurements of $\mathrm{OH}$ sinks made during the field campaign do not close the reactivity budget, with the model suggesting that at least $50 \%$ of carbon-containing compounds which react with $\mathrm{OH}$ were not measured. Modelling indicates that this missing carbon appears to consist of a large number of complex multifunctional organic compounds and it is a challenge to the observational community to better constrain this part of the budget.

From a global perspective, considering the budget of total "emitted" $\mathrm{OH}$ reactivity (including all oxidation products as well as primary species) may offer insights into the fate of organic carbon and ensure that this important property is modelled appropriately by regional, global and earth system models.

Acknowledgements. The authors would like to acknowledge Nick Hewitt and the University of Lancaster OP3 team for help and assistance during the field project. Thanks also to the University of Leeds' electronic and mechanical workshops for help with the continued maintenance of the FAGE instrumentation. Acknowl- 
edgement is made to the Facility for Ground-based Atmospheric Measurements (FGAM), which is part of the NERC National Centre for Atmospheric Science (NCAS), for support of the FAGE and GC instruments used in this research. The project was funded by NERC via grant number NE/D002192/1. We thank the Malaysian and Sabah Governments for their permission to conduct research in Malaysia. This is paper number 530 of the Royal Society's South East Asian Rainforest Research Programme.

Edited by: J. Ma

\section{References}

Bohn, B., Corlett, G. K., Gillmann, M., Sanghavi, S., Stange, G., Tensing, E., Vrekoussis, M., Bloss, W. J., Clapp, L. J., Kortner, M., Dorn, H.-P., Monks, P. S., Platt, U., Plass-Dülmer, C., Mihalopoulos, N., Heard, D. E., Clemitshaw, K. C., Meixner, F. X., Prevot, A. S. H., and Schmitt, R.: Photolysis frequency measurement techniques: results of a comparison within the ACCENT project, Atmos. Chem. Phys., 8, 5373-5391, doi:10.5194/acp-85373-2008, 2008.

Di Carlo, P., Brune, W. H., Martinez, M., Harder, H., Lesher, R., Ren, X., Thornberry, T., Carroll, M., Young, V., Shepson, P., Riemer, D., Apel, E., and Campbell, C.: Missing OH reactivity in a forest: evidence for unknown reactive biogenic VOCs, Science, 304, 722-725, 2004.

Dolgorouky, C., Gros, V., Sarda-Esteve, R., Sinha, V., Williams, J., Marchand, N., Sauvage, S., Poulain, L., Sciare, J., and Bonsang, B.: Total $\mathrm{OH}$ reactivity measurements in Paris during the 2010 MEGAPOLI winter campaign, Atmos. Chem. Phys., 12, 95939612, doi:10.5194/acp-12-9593-2012, 2012.

Emmerson, K. M. and Evans, M. J.: Comparison of tropospheric gas-phase chemistry schemes for use within global models, Atmos. Chem. Phys., 9, 1831-1845, doi:10.5194/acp-9-1831-2009, 2009.

Finlayson-Pitts, B. J. and Pitts, J. N.: Chemistry of the Upper and Lower Atmosphere, Academic Press, 1986.

Goldstein, A. H. and Galbally, I. E.: Known and unexplored organic constituents in the Earth's atmosphere, Environ. Sci. Technol., 41, 1514-1521, doi:10.1021/es072476p, 2007.

Guenther, A., Hewitt, C. N., Erickson, D., Fall, R., Graedel, C. G. A., Harley, P., Klinger, L., Lerdau, M., Pierce, W. A. M. A., Scholes, B., Steinbrecher, R., Tallamraju, R., and Zimmerman, J. T. P.: A global-model of natural volatile organic compound emissions, J. Geophys. Res., 100, 8873-8892, 1995.

Guenther, A., Karl, T., Harley, P., Wiedinmyer, C., Palmer, P. I., and Geron, C.: Estimates of global terrestrial isoprene emissions using MEGAN (Model of Emissions of Gases and Aerosols from Nature), Atmos. Chem. Phys., 6, 3181-3210, doi:10.5194/acp-63181-2006, 2006.

Guenther, A., Hewitt, C. N., Karl, T., Harley, P., and Reeves, C.: Biogenic VOC emissions from African, American and Asian tropical rainforests, EOS Ts. Am. Geophys. Un., 89, Fall Meet. Suppl., Abstract A14C-04, 2008.

Hall, B. D. and Claiborn, C. S.: Measurements of the dry deposition of peroxides to a Canadian boreal forest, J. Geophys. Res., 102, 29343-29353, 1997.
Hall, B. D., Claibor, C. S., and Baldocchi, D.: Measurement and modeling of the dry deposition of peroxides, Atmos. Environ., 33, 577-589, 1999.

Heard, D. E. and Pilling, M. J.: Measurement of $\mathrm{OH}$ and $\mathrm{HO}_{2}$ in the troposphere, Chem. Rev., 103, 5163-5198, 2003.

Hewitt, C. N., Lee, J. D., MacKenzie, A. R., Barkley, M. P., Carslaw, N., Carver, G. D., Chappell, N. A., Coe, H., Collier, C., Commane, R., Davies, F., Davison, B., DiCarlo, P., Di Marco, C. F., Dorsey, J. R., Edwards, P. M., Evans, M. J., Fowler, D., Furneaux, K. L., Gallagher, M., Guenther, A., Heard, D. E., Helfter, C., Hopkins, J., Ingham, T., Irwin, M., Jones, C., Karunaharan, A., Langford, B., Lewis, A. C., Lim, S. F., MacDonald, S. M., Mahajan, A. S., Malpass, S., McFiggans, G., Mills, G., Misztal, P., Moller, S., Monks, P. S., Nemitz, E., Nicolas-Perea, V., Oetjen, H., Oram, D. E., Palmer, P. I., Phillips, G. J., Pike, R., Plane, J. M. C., Pugh, T., Pyle, J. A., Reeves, C. E., Robinson, N. H., Stewart, D., Stone, D., Whalley, L. K., and Yin, X.: Overview: oxidant and particle photochemical processes above a south-east Asian tropical rainforest (the OP3 project): introduction, rationale, location characteristics and tools, Atmos. Chem. Phys., 10, 169-199, doi:10.5194/acp-10-169-2010, 2010.

Hofzumahaus, A., Rohrer, F., Lu, K. D., Bohn, B., Brauers, T., Chang, C. C., Fuchs, H., Holland, F., Kita, K., Kondo, Y., Li, X., Lou, S. R., Shao, M., Zeng, L. M., Wahner, A., and Zhang, Y. H.: Amplified trace gas removal in the troposphere, Science, 324, 1702-1704, 2009.

Holzinger, R., Lee, A., Paw, K. T., and Goldstein, U. A. H.: Observations of oxidation products above a forest imply biogenic emissions of very reactive compounds, Atmos. Chem. Phys., 5, 67-75, doi:10.5194/acp-5-67-2005, 2005.

Ingham, T., Goddard, A., Whalley, L. K., Furneaux, K. L., Edwards, P. M., Seal, C. P., Self, D. E., Johnson, G. P., Read, K. A., Lee, J. D., and Heard, D. E.: A flow-tube based laser-induced fluorescence instrument to measure $\mathrm{OH}$ reactivity in the troposphere, Atmos. Meas. Tech., 2, 465-477, doi:10.5194/amt-2-465-2009, 2009.

Jenkin, M. E., Saunders, S. M., Wagner, V., and Pilling, M. J.: Protocol for the development of the Master Chemical Mechanism, MCM v3 (Part B): tropospheric degradation of aromatic volatile organic compounds, Atmos. Chem. Phys., 3, 181-193, doi:10.5194/acp-3-181-2003, 2003.

Jones, C. E., Hopkins, J. R., and Lewis, A. C.: In situ measurements of isoprene and monoterpenes within a south-east Asian tropical rainforest, Atmos. Chem. Phys., 11, 6971-6984, doi:10.5194/acp-11-6971-2011, 2011.

Karl, T., Potosnak, M., Guenther, A., Clark, D., Walker, J., Herrick, J. D., and Geron, C.: Exchange processes of volatile organic compounds above a tropical rain forest: implications for modeling tropospheric chemistry above dense vegetation, J. Geophys. Res., 109, D18306, doi:10.1029/2004jd004738, 2004.

Kesselmeier, J., Kuhn, U., Wolf, A., Andreae, M. O., Ciccioli, P., Brancaleoni, E., Frattoni, M., Guenther, A., Greenberg, J., Vasconcellos, P. D., de Oliva, T., Tavares, T., and Artaxo, P.: Atmospheric volatile organic compounds (VOC) at a remote tropical forest site in central Amazonia, Atmos. Environ., 34, 4063-4072, 2000.

Kim, S., Guenther, A., Karl, T., and Greenberg, J.: Contributions of primary and secondary biogenic VOC tototal $\mathrm{OH}$ reactivity during the CABINEX (Community Atmosphere-Biosphere INterac- 
tions Experiments)-09 field campaign, Atmos. Chem. Phys., 11, 8613-8623, doi:10.5194/acp-11-8613-2011, 2011.

Koppman, R. (Ed.): Volatile Organic Compounds in the Atmosphere, Blackwell Ltd, London, 2007.

Kovacs, T. A. and Brune, W. H.: Total $\mathrm{OH}$ loss rate measurement, J. Atmos. Chem., 39, 105-122, 2001.

Kovacs, T. A., Brune, W. H., Harder, H., Martinez, M., Simpas, J. B., Frost, G. J., Williams, E., Jobson, T., Stroud, C., Young, V., Fried, A., and Wert, B.: Direct measurements of urban $\mathrm{OH}$ reactivity during Nashville SOS in summer 1999, J. Environ. Mon., 5, 68-74, 2003

Kubistin, D., Harder, H., Martinez, M., Rudolf, M., Sander, R., Bozem, H., Eerdekens, G., Fischer, H., Gurk, C., Klüpfel, T., Königstedt, R., Parchatka, U., Schiller, C. L., Stickler, A., Taraborrelli, D., Williams, J., and Lelieveld, J.: Hydroxyl radicals in the tropical troposphere over the Suriname rainforest: comparison of measurements with the box model MECCA, Atmos. Chem. Phys., 10, 9705-9728, doi:10.5194/acp-10-97052010, 2010.

Kuhn, U., Rottenberger, S., Biesenthal, T., Ammann, C., Wolf, A., Schebeske, G., Oliva, S. T., Tavares, T. M., and Kesselmeier, J.: Exchange of short-chain monocarboxylic acids by vegetation at a remote tropical forest site in Amazonia, J. Geophys. Res., 107, 8069, doi:10.1029/2000JD000303, 2002.

Langford, B., Misztal, P. K., Nemitz, E., Davison, B., Helfter, C., Pugh, T. A. M., MacKenzie, A. R., Lim, S. F., and Hewitt, C. N.: Fluxes and concentrations of volatile organic compounds from a South-East Asian tropical rainforest, Atmos. Chem. Phys., 10, 8391-8412, doi:10.5194/acp-10-8391-2010, 2010.

Lee, J., Young, J., Read, K., Hamilton, J., Hopkins, J., Lewis, A., Bandy, B., Davey, J., Edwards, P., Ingham, T., Self, D., Smith, S., Pilling, M., and Heard, D.: Measurement and calculation of $\mathrm{OH}$ reactivity at a United Kingdom coastal site, J. Atmos. Chem., 64, 53-76, doi:10.1007/s10874-010-9171-0, 2009.

Lelieveld, J., Dentener, F. J., Peters, W., and Krol, M. C.: On the role of hydroxyl radicals in the self-cleansing capacity of the troposphere, Atmos. Chem. Phys., 4, 2337-2344, doi:10.5194/acp4-2337-2004, 2004.

Lelieveld, J., Butler, T. M., Crowley, J. N., Dillon, T. J., Fischer, H., Ganzeveld, L., Harder, H., Lawrence, M. G., Martinez, M., Taraborrelli, D., and Williams, J.: Atmospheric oxidation capacity sustained by a tropical forest, Nature, 452, 737-740, 2008.

Lind, J. A. and Kok, G. L.: Henry's law determinations for aqueous solutions of hydrogen peroxide, methylhydroperoxide, and peroxyacetic acid, J. Geophys. Res., 91, 7889-7895, 1986.

Logan, J. A., Prather, M. J., Wofsy, S. C., and McElroy, M. B.: Tropospheric chemistry: a global perspective, J. Geophys. Res., 86, 7210-7254, 1981.

Lou, S., Holland, F., Rohrer, F., Lu, K., Bohn, B., Brauers, T., Chang, C. C., Fuchs, H., Häseler, R., Kita, K., Kondo, Y., Li, X., Shao, M., Zeng, L., Wahner, A., Zhang, Y., Wang, W., and Hofzumahaus, A.: Atmospheric $\mathrm{OH}$ reactivities in the Pearl River Delta - China in summer 2006: measurement and model results, Atmos. Chem. Phys., 10, 11243-11260, doi:10.5194/acp-10-11243-2010, 2010.

Madronich, S.: The role of solar radiation in atmospheric chemistry, in: Handbook of Environmental Chemistry, edited by: Boule, P., Springer Verlag, Heidelberg, 1-26, 1998.
Matsunaga, S. N., Guenther, A. B., Izawa, Y., Wiedinmyer, C., Greenberg, J. P., and Kawamura, K.: Importance of wet precipitation as a removal and transport process for atmospheric water soluble carbonyls, Atmos. Environ., 41, 790-796, 2007.

Mogensen, D., Smolander, S., Sogachev, A., Zhou, L., Sinha, V., Guenther, A., Williams, J., Nieminen, T., Kajos, M. K., Rinne, J., Kulmala, M., and Boy, M.: Modelling atmospheric OH-reactivity in a boreal forest ecosystem, Atmos. Chem. Phys., 11, 97099719, doi:10.5194/acp-11-9709-2011, 2011.

Nölscher, A. C., Williams, J., Sinha, V., Custer, T., Song, W., Johnson, A. M., Axinte, R., Bozem, H., Fischer, H., Pouvesle, N., Phillips, G., Crowley, J. N., Rantala, P., Rinne, J., Kulmala, M., Gonzales, D., Valverde-Canossa, J., Vogel, A., Hoffmann, T., Ouwersloot, H. G., Vilà-Guerau de Arellano, J., and Lelieveld, J.: Summertime total $\mathrm{OH}$ reactivity measurements from boreal forest during HUMPPA-COPEC 2010, Atmos. Chem. Phys., 12, 8257-8270, doi:10.5194/acp-12-8257-2012, 2012.

Paulot, F., Crounse, J. D., Kjaergaard, H. G., Kroll, J. H., Seinfeld, J. H., and Wennberg, P. O.: Isoprene photooxidation: new insights into the production of acids and organic nitrates, Atmos. Chem. Phys., 9, 1479-1501, doi:10.5194/acp-9-1479-2009, 2009a.

Paulot, F., Crounse, J. D., Kjaergaard, H. G., Kurten, A., St. Clair, J. M., Seinfeld, J. H., and Wennberg, P. O.: Unexpected epoxide formation in the gas-phase photooxidation of isoprene, Science, 325, 730-733, 2009b.

Pearson, G., Davies, F., and Collier, C.: Remote sensing of the tropical rain forest boundary layer using pulsed Doppler lidar, Atmos. Chem. Phys., 10, 5891-5901, doi:10.5194/acp-10-58912010, 2010.

Peeters, J., Nguyen, T. L., and Vereecken, L.: $\mathrm{HO}_{\mathrm{x}}$ radical regeneration in the oxidation of isoprene, Phys. Chem. Chem. Phys., 11, 5935-5939, 2009

Pike, R. C., Lee, J. D., Young, P. J., Carver, G. D., Yang, X., Warwick, N., Moller, S., Misztal, P., Langford, B., Stewart, D., Reeves, C. E., Hewitt, C. N., and Pyle, J. A.: $\mathrm{NO}_{\mathrm{x}}$ and $\mathrm{O}_{3}$ above a tropical rainforest: an analysis with a global and box model, Atmos. Chem. Phys., 10, 10607-10620, doi:10.5194/acp10-10607-2010, 2010.

Pugh, T. A. M., MacKenzie, A. R., Hewitt, C. N., Langford, B., Edwards, P. M., Furneaux, K. L., Heard, D. E., Hopkins, J. R., Jones, C. E., Karunaharan, A., Lee, J., Mills, G., Misztal, P., Moller, S., Monks, P. S., and Whalley, L. K.: Simulating atmospheric composition over a South-East Asian tropical rainforest: performance of a chemistry box model, Atmos. Chem. Phys., 10, 279-298, doi:10.5194/acp-10-279-2010, 2010.

Reeves, C. E. and Penkett, S. A.: Measurements of peroxides and what they tell us, Chem. Rev., 103, 5199-5218, 2003.

Ren, X., Harder, H., Martinez, M., Lesher, R., Oliger, A., Shirley, T., Adams, J., Simpas, J. B., and Brune,W. H.: $\mathrm{HO}_{\mathrm{x}}$ concentrations and $\mathrm{OH}$ reactivity observations in New York City during PMTACS-NY2001, Atmos. Environ., 37, 3627-3637, 2003.

Saunders, S. M., Jenkin, M. E., Derwent, R. G., and Pilling, M. J.: Protocol for the development of the Master Chemical Mechanism, MCM v3 (Part A): tropospheric degradation of nonaromatic volatile organic compounds, Atmos. Chem. Phys., 3, 161-180, doi:10.5194/acp-3-161-2003, 2003.

Shirley, T. R., Brune, W. H., Ren, X., Mao, J., Lesher, R., Cardenas, B., Volkamer, R., Molina, L. T., Molina, M. J., Lamb, B., Velasco, E., Jobson, T., and Alexander, M.: Atmospheric oxida- 
tion in the Mexico City Metropolitan Area (MCMA) during April 2003, Atmos. Chem. Phys., 6, 2753-2765, doi:10.5194/acp-62753-2006, 2006.

Sinha, V., Williams, J., Crowley, J. N., and Lelieveld, J.: The Comparative Reactivity Method - a new tool to measure total $\mathrm{OH}$ Reactivity in ambient air, Atmos. Chem. Phys., 8, 2213-2227, doi:10.5194/acp-8-2213-2008, 2008.

Sinha, V., Williams, J., Lelieveld, J., Ruuskanen, T. M., Kajos, M. K., Patokoski, J., Hellen, H., Hakola, H., Mogensen, D., Boy, M., Rinner, J., and Kulmala, M.: OH reactivity measurements within a boreal forest: evidence for unknown reactive emissions, Environ. Sci. Technol., 44, 6614-6620, 2010.

Sinha, V., Williams, J., Diesch, J. M., Drewnick, F., Martinez, M., Harder, H., Regelin, E., Kubistin, D., Bozem, H., HosaynaliBeygi, Z., Fischer, H., Andrés-Hernández, M. D., Kartal, D., Adame, J. A., and Lelieveld, J.: Constraints on instantaneous ozone production rates and regimes during DOMINO derived using in-situ $\mathrm{OH}$ reactivity measurements, Atmos. Chem. Phys., 12, 7269-7283, doi:10.5194/acp-12-7269-2012, 2012.

Stone, D., Evans, M. J., Commane, R., Ingham, T., Floquet, C. F. A., McQuaid, J. B., Brookes, D. M., Monks, P. S., Purvis, R., Hamilton, J. F., Hopkins, J., Lee, J., Lewis, A. C., Stewart, D., Murphy, J. G., Mills, G., Oram, D., Reeves, C. E., and Heard, D. E.: $\mathrm{HO}_{\mathrm{x}}$ observations over West Africa during AMMA: impact of isoprene and $\mathrm{NO}_{\mathrm{x}}$, Atmos. Chem. Phys., 10, 9415-9429, doi:10.5194/acp-10-9415-2010, 2010.

Stone, D., Evans, M. J., Edwards, P. M., Commane, R., Ingham, T., Rickard, A. R., Brookes, D. M., Hopkins, J., Leigh, R. J., Lewis, A. C., Monks, P. S., Oram, D., Reeves, C. E., Stewart, D., and Heard, D. E.: Isoprene oxidation mechanisms: measurements and modelling of $\mathrm{OH}$ and $\mathrm{HO}_{2}$ over a South-East Asian tropical rainforest during the OP3 field campaign, Atmos. Chem. Phys., 11, 6749-6771, doi:10.5194/acp-11-6749-2011, 2011.
Stone, D., Whalley, L. K., and Heard, D.E.: Tropospheric OH and $\mathrm{HO}_{2}$ radicals: field measurements and model comparisons, Chem. Soc. Rev., 41, 6348-6404, 2012.

Tan, D., Faloona, I., Simpas, J. B., Brune, W., Shepson, P. B., Couch, T. L., Sumner, A. L., Carrol, M. A., Thornberry, T., Apel, E., Riemer, D., and Stockwell, W.: $\mathrm{HO}_{\mathrm{x}}$ budgets in a deciduous forest: results from the PROPHET summer 1998 campaign, J. Geophys. Res. Atmos., 106, 24407-24427, 2001.

Valverde-Canossa, J., Ganzeveld, L., Rappenglück, B., Steinbrecher, R., Klemm, O., Schuster, G., and Moortgat, G. K.: First measurements of $\mathrm{H}_{2} \mathrm{O}_{2}$ and organic peroxides surface fluxes by the relaxed eddy-accumulation technique, Atmos. Environ., 40, 55-67, 2006.

Whalley, L. K., Furneaux, K. L., Goddard, A., Lee, J. D., Mahajan, A., Oetjen, H., Read, K. A., Kaaden, N., Carpenter, L. J., Lewis, A. C., Plane, J. M. C., Saltzman, E. S., Wiedensohler, A., and Heard, D. E.: The chemistry of $\mathrm{OH}$ and $\mathrm{HO}_{2}$ radicals in the boundary layer over the tropical Atlantic Ocean, Atmos. Chem. Phys., 10, 1555-1576, doi:10.5194/acp-10-1555-2010, 2010.

Whalley, L. K., Edwards, P. M., Furneaux, K. L., Goddard, A., Ingham, T., Evans, M. J., Stone, D., Hopkins, J. R., Jones, C. E., Karunaharan, A., Lee, J. D., Lewis, A. C., Monks, P. S., Moller, S. J., and Heard, D. E.: Quantifying the magnitude of a missing hydroxyl radical source in a tropical rainforest, Atmos. Chem. Phys., 11, 7223-7233, doi:10.5194/acp-11-7223-2011, 2011.

Wolfe, G. M. and Thornton, J. A.: The Chemistry of AtmosphereForest Exchange (CAFE) Model - Part 1: Model description and characterization, Atmos. Chem. Phys., 11, 77-101, doi:10.5194/acp-11-77-2011, 2011. 